\title{
Olivine-Melt Relationships and Syneruptive Redox Variations in the 1959 Eruption of Kīlauea Volcano as Revealed by XANES
}

Helz, R.T. ${ }^{a}$, Cottrell, E. ${ }^{b}$, Brounce, M.N. ${ }^{c}$ and Kelley, K.A. ${ }^{d}$

a. U.S. Geological Survey, M.S. 926A, Reston, VA 20192 USA

b. Smithsonian Institution, P.O. Box 37012, National Museum of Natural History MRC-119, Washington D.C. 20013, USA.

c. Division of Geological and Planetary Sciences, California Institute of Technology, Pasadena CA 91125, USA

d. Graduate School of Oceanography, University of Rhode Island, Narragansett, RI 02882, USA

Corresponding author R.T. Helz, email rhelz@usgs.gov

(C) 2016. This manuscript version is made available under the Elsevier user license 


\section{$\underline{\text { Abstract }}$}

The 1959 summit eruption of Kîlauea Volcano exhibited high lava fountains of gas-rich, primitive magma, containing olivine + chromian spinel in highly vesicular brown glass. Microprobe analysis of these samples shows that euhedral rims on olivine phenocrysts, in direct contact with glass, vary significantly in forsterite (Fo) content, at constant major-element melt composition, as do unzoned groundmass olivine crystals.. Ferric/total iron $\left(\mathrm{Fe}^{+3} / \mathrm{Fe}^{\mathrm{T}}\right)$ ratios for matrix and interstitial glasses, plus olivine-hosted glass inclusions in eight 1959 scoria samples have been determined by micro X-ray absorption near-edge structure spectroscopy ( $\mu$-XANES). These data show that much of the variation in Fo content reflects variation in oxidation state of iron in the melt, which varies with sulfur concentration in the glass and (locally) with proximity to scoria edges in contact with air. Data for 24 olivine-melt pairs in the better-equilibrated samples from later in the eruption show $\mathrm{K}_{\mathrm{D}}$ averaging $0.280 \pm 0.03$ for the exchange of $\mathrm{Fe}$ and $\mathrm{Mg}$ between olivine and melt, somewhat displaced from the value of $0.30 \pm 0.03$ given by Roeder and Emslie (1970). This may reflect the low $\mathrm{SiO}_{2}$ content of the 1959 magmas, which is lower than that in most Kîlauea tholeiites. More broadly, we show the potential of $\mu$-XANES and electron microprobe to revisit and refine the value of $\mathrm{K}_{\mathrm{D}}$ in natural systems.

The observed variations of $\mathrm{Fe}^{+3} / \mathrm{Fe}^{\mathrm{T}}$ ratios in the glasses reflect two distinct processes. The main process, sulfur degassing, produces steady decrease of the $\mathrm{Fe}^{+3} / \mathrm{Fe}^{\mathrm{T}}$ ratio. Melt inclusions in olivine are high in sulfur (1060-1500 ppm S), with $\mathrm{Fe}^{+3} / \mathrm{Fe}^{\mathrm{T}}=0.160-0.175$. Matrix glasses are degassed (mostly $\mathrm{S}<200 \mathrm{ppm}$ ) with generally lower $\mathrm{Fe}^{+3} / \mathrm{Fe}^{\mathrm{T}}(0.114-0.135)$. Interstitial glasses within clumps of olivine crystals locally show intermediate levels of sulfur and $\mathrm{Fe}^{+3} / \mathrm{Fe}^{\mathrm{T}}$ ratio. The correlation suggests that (1) the 1959 magma was significantly reduced 
by sulfur degassing during the eruption and (2) the melts originally had $\mathrm{Fe}^{+3} / \mathrm{Fe}^{\mathrm{T}} \geq 0.175$, consistent with oxygen fugacity $\left(f \mathrm{O}_{2}\right)$ at least $0.4 \mathrm{log}$ units above the fayalite-magnetite-quartz (FMQ) buffer at 1 atmosphere and magmatic temperature of $1200^{\circ} \mathrm{C}$.

The second process is interaction between the melts and atmospheric oxygen, which results in higher $\mathrm{Fe}^{+3} / \mathrm{Fe}^{\mathrm{T}}$ ratios. Detailed $\mu$-XANES traverses show gradients in $\mathrm{Fe}^{+3} / \mathrm{Fe}^{\mathrm{T}}$ of 0.145 to 0.628 over distances of $100-150$ micrometers in thin, visibly reddened matrix glass bordering some scoriae, presumably caused by contact with air. This process was extremely rapid, giving insight into how fast the $\mathrm{Fe}^{+3} / \mathrm{Fe}^{\mathrm{T}}$ ratio can change in response to changes in external conditions.

Keywords: redox state, sulfur degassing, basalt, Kîlauea, olivine-melt Mg-Fe exchange

\section{$\underline{1.1 \text { Introduction }}$}

The 1959 summit eruption is unique in Kīlauea's historic record for its highly magnesian, olivine-rich lavas (Murata and Richter, 1966) and very high fountain heights (up to $580 \mathrm{~m}$, Richter et al., 1970). Most 1959 scoria samples contain only olivine + chromite + glass. Microprobe analysis of the glasses in these scoriae show that their $\mathrm{MgO}$ contents range from 6.4 to 10.2 weight percent, with the bulk of them having $\mathrm{MgO}=8.0-9.0$ weight percent $(\mathrm{Helz}, 1987$, 2009a; Helz et al., 2014a). These values correspond to quenching temperatures of 1143 to $1220^{\circ} \mathrm{C}$, with most scoria falling between 1170 and $1220^{\circ} \mathrm{C}$ (Helz and Thornber, 1987). It might be supposed that such high-temperature samples would be well-equilibrated, but Helz (1987) documented extensive textural and chemical disequilibrium in the scoria. The present study was undertaken to constrain the ferric/total iron $\left(=\mathrm{Fe}^{+3} / \mathrm{Fe}^{\mathrm{T}}\right)$ ratio of the 1959 scoria glasses in situ, in order to calculate $\mathrm{K}_{\mathrm{D}}$ values for $\mathrm{Mg}$-Fe exchange between coexisting olivine-melt pairs directly. We use these data to assess the degree of internal equilibration in the 1959 lavas, and to 
evaluate the extent of redox heterogeneity present in the 1959 scoria and the processes responsible for observed variations over a range of spatial and temporal scales.

\subsection{Background and context for this study}

The 1959 summit eruption of Kīlauea volcano involved 17 distinct phases of high lava fountaining, extending over a period of 5 weeks; Richter et al. (1970) provide a detailed log of the observed activity. The eruption was also monitored seismicallyby Eaton and Murata(1960), who tracked earthquakes as they ascended from mantle depths of 40-60 km to the summit reservoir, in the weeks prior to the eruption. Their arrival coincided with the onset of the eruption in Kīlauea Iki pit crater. Whole-rock chemistry by Murata and Richter (1966) allowed Wright (1973) to recognize two distinct chemical batches, distinguishable especially by differences in $\mathrm{CaO}$ content at constant $\mathrm{MgO}$ content. Wright (1973) described each sample as consisting of a mixture of the high- $\mathrm{CaO}$ component, represented in the calculations by the composition of S-1 (sample Iki-58, from the east end of the initial eruptive fissure) plus the low$\mathrm{CaO}$ component S-2 (sample Iki-1, from the west end of the initial fissure), plus variable amounts of olivine and chromite. Subsequent work (Helz, 1987, 2009a) showed that all glasses in the 1959 scoria were more magnesian than samples S-1 and S-2; because of this, Helz (1987) suggested that the two components be renamed 1959E (the high-CaO component) and 1959W (the low- $\mathrm{CaO}$ component), and that convention is followed below. The variation of $\mathrm{MgO}$ in 1959 scoria glasses over the course of the eruption is shown in Fig. 1. The glasses fall into three categories, based on the mixing ratios of Wright (1973): those with 31-70\% of the juvenile (1959E) component in the groundmass, those almost entirely made up of the stored (1959W) component, and later hybrids, which have intermediate mixing ratios (mostly near 20\% juvenile, 
$80 \%$ stored component). Analyses of glasses in samples high in the 1959E component generally have higher $\mathrm{MgO}$ contents than other samples, during the early and middle stages of the eruption. Because all 1959 glasses contain olivine, and the $\mathrm{MgO}$ content of olivine-saturated glasses varies linearly with temperature (Helz and Thornber, 1987), the 1959E-rich glasses are therefore mostly hotter than the $1959 \mathrm{~W}$-rich glasses. This is consistent with the $1959 \mathrm{E}$ component being the new component injected into the magma chamber, the arrival of which destabilized Kīlauea's summit reservoir and triggered the eruption (Eaton and Murata, 1960; Helz, 1987; Eaton et al., 1987; Helz et al., 2014a).

Olivine compositions have been analyzed previously in most of these samples. Fig. 2a shows how compositions of euhedral rims for olivine phenocrysts ( Helz, 1987; 2009b) vary over the course of the eruption. There is a marked lack of correlation between glass $\mathrm{MgO}$ content (Fig. 1) and olivine rim compositions. For example, in samples from phases 1 and 2 (positions 1-13in Figs. 1-2) the maximum forsterite content of olivine phenocryst rims is near $\sim \mathrm{Fo}_{88}$ even though glass $\mathrm{MgO}$ content is notably lower in the $1959 \mathrm{~W}$-rich samples. Also, in several of the latest samples (from phases 10-16), olivine rim compositions are $\sim \mathrm{Fo}_{86}$ or less, while their coexisting glasses have the same maximum and range of $\mathrm{MgO}$ contents as samples erupted from as early as phase 6 (positions 17-22 in Figs. 1 and 2a). Inspection of these data show that the euhedral olivine rims, though apparently in textural equilibrium with the enclosing melt, cannot all be in chemical equilibrium with the melts they touch, if $\mathrm{Fe}^{+3} / \mathrm{Fe}^{\mathrm{T}}$ is constant in the melt.

Compositional data for the population of smaller (microphenocrystic to groundmass, $<1 \mathrm{~mm}$ in length) euhedral olivines found in these same samples is shown in Fig. 2b. These vary widely in composition, often by more than phenocryst rims, and they extend to lower Fo contents. Like the phenocrysts, they cannot all be in equilibrium with the glasses in which they 
are found, if melt $\mathrm{Fe}^{+3} / \mathrm{Fe}^{\mathrm{T}}$ is constant within a given scoria. However, in some of the latest samples (from phases 10-16), the range of composition of the smaller olivines is similar to the range in phenocryst rims, suggesting that by the latter part of the eruption, olivine and melt were approaching equilibrium with each other, as was noted by Helz (1987, 2009b).

The data in Figs. 1 and 2 were used to evaluate olivine-melt relations, using the experimental results of Roeder and Emslie (1970) for the exchange of $\mathrm{Mg}$ and $\mathrm{Fe}^{+2}$ between olivine and melt (Helz, 2009). Results, based solely on microprobe analyses, included (1) $\mathrm{K}_{\mathrm{D}}$ appeared to vary with grainsize, suggesting that $\mathrm{Fe}^{+3} / \mathrm{Fe}^{\mathrm{T}}$ varied during progressive nucleation of olivine, (2) the pattern suggested reduction of the melt during eruption and (3) $\mathrm{Fe}^{+3} / \mathrm{Fe}^{\mathrm{T}}$ ratios were higher than usually reported for Kîlauea basalts. These findings motivated the present study and provided the basis for sample selection.

\section{$\underline{\text { 2.1 Selection and Description of Samples for } \mu \text {-XANES Analysis }}$}

Based on preliminary investigations described above, we selected he eight samples, all of known bulk composition, for further analysis:

(1) Two samples are hybrids from from late in the eruption (Iki-26 and Iki-32).

(2) Three are phase 1 samples rich in the 1959E component (Iki-2, Iki-22 and Iki-3). These cover most of the range of bulk and glass $\mathrm{MgO}$ contents within this group.

(3) Three are samples rich in the $1959 \mathrm{~W}$ component (Iki-44 and Iki-5 from phase 1 of the eruption and Iki-10 [with 100\% 1959W; see Wright, 1973] from phase 3 of the eruption). Again, these cover the range of bulk and glass $\mathrm{MgO}$ contents within this group.

These samples are labeled in Fig. 1 and data on the time of their eruption and height of 
associated fountaining are given in Table 1. These and all other scoria were collected from the periphery of the area of deposition of scoria, at known times, during the eruption. There has been little opportunity for post-eruptive re-equilibration or alteration of either glass or olivine.

The samples consist of highly vesicular brown glass with varying amounts of olivine. The olivine crystals range in size from several millimeters to a few micrometers in length; larger crystals often occur in clusters (as reported in Schwindinger et al., 1989). Inclusions in olivine are chromite, melt (now glass), and rarely, blebs of immiscible sulfide. Representative views of analyzed areas for three samples are shown in Figs. 3a,b, and c. The bulk olivine content of these samples varies from 28 weight percent in Iki-26 to $7 \%$ in Iki-5, as calculated from the bulk compositions in Murata and Richter (1966).

\section{$\underline{3.1 \text { Analytical methods for microprobe analyses and glass compositions }}$}

The glass analyses reported here were obtained using the electron microprobe at the USGS, Reston, VA. Standards used included Makaopuhi glass A99 for most major elements, with $\mathrm{Na}, \mathrm{K}, \mathrm{P}, \mathrm{Mn}, \mathrm{Cr}$, and S referred to other standards. Operating conditions were $15 \mathrm{keV}$, beam current 20 nanoamps, with a spot size of 10 microns. Counting times were 20 seconds (peak) and 10 seconds (background) except for $\mathrm{P}$ (40 seconds, 20 seconds) and sulfur (60 seconds, 30 seconds). Because of the long count times used, the reproducibility of sulfur is \pm 60 ppm, both at $1400 \mathrm{ppm}$ and $142 \mathrm{ppm}$. This is based on the dispersion in sulfur values observed for two standard glasses (VG-2 and A99) as reported in Helz et al. (2014b, Appendix Table A2, page 3).

Olivine analyses were also obtained at the USGS, Reston, VA, using appropriate natural and synthetic standards. Operating conditions were $15 \mathrm{keV}$, beam current 20 nanoamps, but with 
a spot size of $\sim 2$ microns. Counting times were 20 seconds (peak) and 10 seconds (background).

Grains analyzed varied from 1-3 mm long (phenocrysts) down to $<10$ microns. Rim compositions on phenocrysts were taken within 1-3 microns of the edge of the grain. The compositions of the San Carlos and Marjahlati olivines were monitored to verify that analytical results were consistent from one EPMA session to the next.

For melt inclusions, glass embayments, and areas of interstitial glass, the $\mu$-XANES determinations were made first, and the microprobe analyses later. In a few cases, glass analyses are given for additional inclusions or interstitial areas, but for which $\mu$-XANES determinations either were not made or were not possible. These are included in Appendix A to show the prevalence of elevated sulfur in such glasses.

Inclusion glasses, glass embayments, and interstitial glasses in Iki-22 and Iki-3 were reconstructed by adding enough olivine to the glass composition to bring the $\mathrm{MgO}$ in the glass up to the average $\mathrm{MgO}$ content seen in the glasses away from olivine crystals and clusters. The olivine composition used was that immediately adjacent to the inclusion, embayment or interstitial area. The amounts of olivine needed were modest, ranging from 0.8 to 2.5 weight percent olivine. Inclusion and semi-enclosed glasses in samples Iki-2, Iki-44, Iki-5, Iki-26, and Iki-32 have $\mathrm{MgO}$ contents that match the average glasses away from olivine, so appeared to involve little or no late overgrowth of olivine.

The average matrix glass compositions for areas analyzed in this study are shown in Table 2; the complete set of glass analyses is in Appendix A. The glasses investigated here have average $\mathrm{MgO}$ contents ranging from 10.14 to $7.48 \% \mathrm{MgO}$, corresponding to quenching temperatures of $1220^{\circ}$ to $1164^{\circ} \mathrm{C}$ (Helz and Thornber, 1987). 


\subsection{Method of Determination of Oxidation State of the Glasses}

From previous work on the 1959 scoria, it was apparent that direct determination of the oxidation state of the 1959 glasses would be essential to understanding the observed olivine-melt relations (Helz, 2009b). Synchrotron-based micro X-ray absorption near-edge structure ( $\mu$ XANES) spectroscopy provides $\mathrm{Fe}^{3+} / \mathrm{Fe}^{\mathrm{T}}$ ratios in situ (in thin section with an $\mathrm{Fe}$-free slide) with high spatial resolution (e.g. Berry et al., 2003; Wilke et al., 2005; Cottrell et al., 2009). All samples were analyzed in situ for $\mathrm{Fe}^{3+} / \mathrm{Fe}^{\mathrm{T}}$ ratios following the XANES methods and techniques of Cottrell et al. (2009) at beamline X26A, National Synchrotron Light Source, Brookhaven National Laboratory. Spectra were collected in fluorescence mode from $7020 \mathrm{eV}$ to $7220 \mathrm{eV}$ using a $\mathrm{Si}$ [311] monochromator and a spot size of $\sim 5 \mathrm{x} 9$ microns. All spectra were collected, using both a single 4-element Vortex ME-4 silicon drift diode detector and two single element Vortex-Ex detectors (Hitachi) coupled to an XMap digital spectrometer system (XIA). The monochromator energy at X26A was calibrated so that the first derivative peak for Fe K-edge spectra for Fe foil was $7112.0 \mathrm{eV}$ (Ruffoni and Pettifer, 2006). Incident beam flux at X26A for these experiments was $\sim 3 \times 10^{9}$ photons/sec. Reference glass LW-0 (Cottrell et al., 2009) was monitored continuously during each experimental session to correct for instrumental drift and data were normalized to a pre-edge centroid value of $L W \_0=7112.3 \mathrm{eV}$. Further details of this analytical procedure and the drift correction can be found in Cottrell et al. (2009).

We calibrated the XANES spectra using a suite of 13 basaltic glass standards, which were calibrated originally by Cottrell et al. (2009) using room temperature Mossbauer spectroscopy. New cryogenic (10 K) Mossbauer spectra of these same glasses suggests a

correction factor, $C$, of 1.1, where $\left[\mathrm{Fe}^{3+} / \mathrm{Fe}^{\mathrm{T}}(\right.$ corrected $\left.)\right]=\left[\mathrm{Fe}^{3+} / \mathrm{Fe}^{\mathrm{T}}(\mathrm{RT})\right] /\left(\left[\mathrm{Fe}^{3+} / \mathrm{Fe}^{\mathrm{T}}(\mathrm{RT})\right]+C(1-\right.$ $\left[\mathrm{Fe}^{3+} / \mathrm{Fe}^{\mathrm{T}}(\mathrm{RT})\right]$ ), owing to recoilless fraction effects (Hirschmann et al., 2015). In light of this, 
we have elected here to correct our measured $\mathrm{Fe}^{+3} / \mathrm{Fe}^{\mathrm{T}}$ ratios by -0.01 (absolute) relative to the original calibration of Cottrell et al. (2009). Note that if a correction of -0.01 (absolute) is applied, the median $\mathrm{Fe}^{+3} / \mathrm{Fe}^{\mathrm{T}}$ ratio of MORB glasses is $\sim 0.15$. This approach yields a precise determination of the $\mathrm{Fe}^{+3} / \mathrm{Fe}^{\mathrm{T}}$ ratio in basaltic glasses, with a 1-sigma precision of \pm 0.005 absolute, and an estimated accuracy of \pm 0.01 absolute. We emphasize that the key results of the present work relate to the relative, within- and between-sample variations in $\mathrm{Fe}^{+3} / \mathrm{Fe}^{\mathrm{T}}$ ratios; these are clearly resolved by the high precision of XANES analysis and are independent of the accuracy of the method.

A key requirement for a successful XANES measurement is that the glass be the only iron-bearing phase in the path of the beam during analysis. For instance, olivine contains several weight percent of $\mathrm{Fe}^{2+}$ and even a small amount of olivine in the beam path will influence the shape of pre-edge structure in $\mathrm{Fe}-\mu$-XANES spectra, and bias the calculated $\mathrm{Fe}^{+3} / \mathrm{Fe}^{\mathrm{T}}$ ratio to more reduced values (Kelley \& Cottrell, 2012; Brounce et al., 2014). Accordingly, all samples were mounted on 1-inch circular slides of iron-free silica glass and polished for microprobe and XANES analysis. Transmitted and reflected light photomicrographs were used to select areas of clear glass, which was possible even in highly vesicular samples, and also to analyze glass in embayments and inclusions in olivine crystals, some of which are illustrated in Fig. 3. Spectra were scrutinized for evidence of any influence from host olivines, phenocrysts, or microphenocrysts. If crystal interference was found, these spectra were eliminated from further study.

\subsection{XANES results for 1959 scoria glasses}

Analysis of Iki-22, Iki-3, Iki-26, and Iki-32 revealed ranges in $\mathrm{Fe}^{+3} / \mathrm{Fe}^{\mathrm{T}}$ ratios larger than 
those observed on MORB sections (Table 2). Initially, three points were taken on each sample, because previous experience in analyzing $\mathrm{Fe}^{+3} / \mathrm{Fe}^{\mathrm{T}}$ ratios suggested that this ratio would be nearly constant $(1 \sigma<0.008$ absolute) in basaltic glasses within a thin section or melt inclusion (Cottrell and Kelley, 2011, Kelley and Cottrell, 2012; Brounce et al., 2014). Given the largerthan-expected ranges in $\mathrm{Fe}^{+3} / \mathrm{Fe}^{\mathrm{T}}$ ratio, we selected additional areas and additional samples for detailed analysis. We took care to obtain XANES spectra on glass adjacent to particular olivine grains co-located with the electron microprobe analysesFig. 3a, b and c show three such areas. The co-located microprobe and XANES data are in Appendix A, while Appendix B includes complete, fully annotated photomicrographs of the areas analyzed.

All of the XANES determinations of $\mathrm{Fe}^{+3} / \mathrm{Fe}^{\mathrm{T}}$ made in this study, plotted in eruption sequence are shown in Fig. 4; the size of the symbols used is comparable to the estimated accuracy of Mossbauer $( \pm 0.01$ absolute $)$. These values have the $-1 \%$ correction applied, so differ from the values reported earlier (Helz et al., 2014c, 2015). There are a total of 78 determinations, including some on glass inclusions, plus interstitial and embayment glasses in olivine crystals and crystal clusters.

When one compares the 1959 glasses with the range of $\mathrm{Fe}^{+3} / \mathrm{Fe}^{\mathrm{T}}$ ratios observed in MORBs (from Cottrell and Kelley, 2011, see their Fig. 4 and apply a shift of -0.01 to all data), it is clear (1) that most of the individual Kîlauea scoriae have a range of $\mathrm{Fe}^{+3} / \mathrm{Fe}^{\mathrm{T}}$ values equal to or larger than seen in the $>100$ MORB glass analyses from three ocean basins analyzed to date, and (2) there is no systematic shift in oxidation state of the glasses with time over the five weeks of the eruption. As reported below, detailed $\mu$-XANES traverses show gradients in $\mathrm{Fe}^{+3} / \mathrm{Fe}^{\mathrm{T}}$ ratios of 0.145 to 0.628 over distances of $100-150$ micrometers in thin, visibly reddened matrix glass bordering some scoriae. These values are remarkable both because of the large gradient 
and because we have not previously seen $\mathrm{Fe}^{+3} / \mathrm{Fe}^{\mathrm{T}}$ ratios greater than 0.35 in basalt from any tectonic setting. The results suggest that some of the disequilibrium inferred by comparing data in Fig.s 1 and 2 may indeed result from analytically significant variations in oxidation state of iron within individual 1959 scoria samples.

\subsection{Evaluation of the Exchange of $\mathrm{Mg}$ and Fe between Olivine and Melt}

Olivine and basaltic melts equilibrate with each other by the exchange of magnesium and ferrous $\left(\mathrm{Fe}^{+2}\right)$ ions, according to the equation

$$
\left.\left.\mathrm{Fe}^{+2}(\text { melt })+\mathrm{Mg}^{+2}(\text { olivine }) \leftrightarrow \mathrm{Mg}^{+2} \text { (melt }\right)+\mathrm{Fe}^{+2} \text { (olivine }\right)
$$

The equilibrium distribution coefficient $\left(\mathrm{K}_{\mathrm{D}}\right)$ for this equation is written

$$
\mathrm{K}_{\mathrm{D}}=\left[\mathrm{Fe}^{+2} / \mathrm{Mg}\right]_{\text {olivine }} /\left[\mathrm{Fe}^{+2} / \mathrm{Mg}\right]_{\text {melt }}
$$

The exchange of $\mathrm{Fe}^{+2}$ and $\mathrm{Mg}$ between olivine and silicate melts was first studied by Roeder and Emslie (1970). They performed 1- atmosphere melting experiments under known temperature and controlled oxygen fugacity conditions. They equilibrated three natural basaltic samples, and reported that $K_{D}=0.30 \pm 0.03$, if they combined the results from all three samples together. Ferric iron does not participate in this exchange reaction, as the amount of $\mathrm{Fe}^{+3}$ that can be accommodated in olivine is negligible. Therefore it was necessary to determine the oxidation state of iron in the 1959 samples directly, in order to be able to calculate $\mathrm{Fe}^{+2}$ content, and then to evaluate the state of olivine-melt equilibration in the samples.

\subsection{1 $\mathrm{K}_{\mathrm{D}}$ Results for the Late Scoria Samples}

The present study combines XANES data with microprobe analyses of coexisting olivine and melt immediately adjacent to individual XANES determinations. $\mathrm{Fe}^{+3} / \mathrm{Fe}^{\mathrm{T}}$ ratios allow direct calculation of $\mathrm{Fe}^{+2}$ contents in the melt, and hence direct calculation of the distribution 
coefficient $\left(\mathrm{K}_{\mathrm{D}}\right)$, for the exchange of $\mathrm{Fe}^{+2}$ and $\mathrm{Mg}$ between olivine in these samples, assuming all $\mathrm{Fe}$ in olivine is $\mathrm{Fe}^{+2}$. Fig. 5 shows the results for five areas in Iki-26 and Iki-32, samples that from previous work appeared to be relatively well-equilibrated. The $K_{D}$ values from 24 olivinemelt pairs in these two samples fall between values of $0.260-0.290$; the arithmetic average value is $K_{D}=0.280$ for all values in Appendix A.

There are two overlapping distributions, one of melts in contact with olivine phenocryst rims plus olivine rimming a melt inclusion (in gray), and a separate distribution for melts in contact with microphenocrystic and groundmass olivine crystals, in agreement with earlier results (Helz, 2009b). That study assumed that $\mathrm{K}_{\mathrm{D}}=0.30$, however, and led to an estimated $\mathrm{Fe}^{+3} / \mathrm{Fe}^{\mathrm{T}}$ for the late samples of $20-25 \%$, higher than most of the XANES determinations reported here.

The range of $\mathrm{Fe}^{+3} / \mathrm{Fe}^{\mathrm{T}}$ ratios observed in glasses coexisting with olivine is substantial, varying from 0.127 to 0.233 . A plot of $\mathrm{K}_{\mathrm{D}}$ vs. $\mathrm{Fe}^{+3} / \mathrm{Fe}^{\mathrm{T}}$ (Fig. 6) shows that the $\mathrm{K}_{\mathrm{D}}$ for $\mathrm{Fe}^{+2}$ - $\mathrm{Mg}$ exchange in these samples varies little as $\mathrm{Fe}^{+3} / \mathrm{Fe}^{\mathrm{T}}$ increases over a factor of two, and that $60 \%$ of the data fall within \pm 0.01 of 0.280 . The lack of dependence of $\mathrm{KD}$ on $\mathrm{Fe}^{+3} / \mathrm{Fe}^{\mathrm{T}}$ is in agreement with the results of Roeder and Emslie (1970), who found no dependence of $K_{D}$ over a wide range of oxygen fugacity.

\subsubsection{Results for Scoria from Phase 1 of the 1959 Eruption}

The range of $K_{D}$ values observed for coexisting olivine-melt pairs in the phase 1 samples rich in the 1959E (juvenile) component are shown in Fig. 7 and samples rich in the 1959W (stored) component in Fig. 8. As noted earlier, all phenocryst pairs included here are class 2 euhedral crystals $(\mathrm{Helz}, 1987)$ that are either $>1 \mathrm{~mm}$ in length or are part of a cluster of olivine crystals, some of which are $>1 \mathrm{~mm}$ in length; an example is shown in Fig. 3b. Prior study ( Helz, 
1987) has shown that attached olivines within a cluster are all similar in composition, regardless of the size of the individual crystal. Pairs involving independent microphenocryst or groundmass olivine crystals are again shown separately, as the composition of those olivines can vary independently of that of the phenocrysts (Fig. 2b, and Helz, 2009b).

Results for the 1959E-rich samples are similar to those for the late scoria samples, in that they fall into two overlapping distributions. This is in contrast to earlier results (Helz, 2009b), in which there appeared to be significant offset in either $\mathrm{K}_{\mathrm{D}}$ or in estimated $\mathrm{Fe}^{+3} / \mathrm{Fe}^{\mathrm{T}}$ between the large and small olivines. Thus some of the heterogeneity in the 1959 scoria is indeed related to shifts in $\mathrm{Fe}^{+3} / \mathrm{Fe}^{\mathrm{T}}$ of the melt as the olivines crystallized. The overall range of $\mathrm{K}_{\mathrm{D}}$ values is wider, and the median value ( 0.26) somewhat lower than in the late samples (Iki-26, Iki-32). The olivine-melt pairs associated with the embayed microphenocryst shown in Fig. 3a have $\mathrm{K}_{\mathrm{D}}$ $=0.30-0.31$, making that crystal an anomaly in this set of samples. It appears to be cognate to the 1959W component rather than the 1959E melts.

In contrast to the histograms in Fig.s 5 and 7, the distribution of $K_{D}$ values seen in the 1959W samples (Fig. 8) is irregular, with few olivine-melt pairs falling in the 0.25-0.31 range that encompasses most of the pairs in the late and 1959E samples. In fact most of the pairs fall between 0.19 and 0.23 , a range sparsely represented in the 1959E-rich samples and absent in the late samples. Thus the data on Iki-44 and Iki-5 show that most olivine-melt pairs in those samples are far from being in equilibrium with each other, even with known $\mathrm{Fe}^{+3} / \mathrm{Fe}^{\mathrm{T}}$ ratios. The simplest interpretation is that the olivine phenocrysts in these samples did not originate in the stored magmatic component that now hosts them. Glass analyses of melt inclusions in olivines (Table 4) show all four to be rich in the high-CaO 1959E component, regardless of the affinity of the matrix glasses (Table 2). This includes the examples found in Iki-44 and Iki-5, 
and is consistent with earlier results of Anderson and Brown (1993) on a larger population of melt inclusions in olivines of the 1959 eruption.

\section{$\underline{5.1 \text { Discussion of Results on Olivine-Melt Relations }}$}

The original impetus for this study was to resolve some of the complications found in Helz (2009b), including an apparent dependence of the $\mathrm{Fe}^{+3} / \mathrm{Fe}^{\mathrm{T}}$ ratio on grainsize of olivine. All three histograms (Figs. 5, 7, and 8) show that knowledge of $\mathrm{Fe}^{+3} / \mathrm{Fe}^{\mathrm{T}}$ values eliminates this peculiarity, as the groundmass olivine compositions do reflect a measurable decrease in the redox state in the matrix glasses. The extent of $\mathrm{Fe}^{+2}-\mathrm{Mg}$ exchange disequilibrium between olivine and melt, which is higher in the phase 1 samples than in the late samples, is related to recent magma mixing between the 1959E and 1959W components, and will be explored in a later paper.

There is one remaining problem: As noted in the discussion of Fig. $5, \mathrm{~K}_{\mathrm{D}}$ values in the late samples cluster very tightly around an average value of 0.280 , for 24 olivine-melt pairs, with $\mathrm{Fe}^{+3} / \mathrm{Fe}^{\mathrm{T}}$ ranging from $0.127-0.233$. It is also observed for pairs in other samples, especially those with groundmass olivine, though not as consistently. The value appears to be fairly robust, but is somewhat lower than the original value of $K_{D}=0.30 \pm 0.03$ given by Roeder and Emslie (1970). The question arises: why are the $\mathrm{K}_{\mathrm{D}}$ values obtained here different?

Recent re-evaluation of Roeder and Emslie's work by Matzen et al. (2011 and electronic supplement) suggests that $K_{D}$ did vary somewhat with basalt composition in these pioneering experiments. Roeder and Emslie (1970) included five experiments on two relatively low-silica, high- $\mathrm{CaO}$ samples in their data set. For the five runs on these compositions, the re-evaluated results have $K_{D}=0.28$ on average, the value observed for the olivine-melt pairs in the late 1959 
samples (fig. 5). By contrast, their olivine tholeiite by itself has $K_{D}=0.31-0.32$ (Matzen et al., 2011).

The 1959 Kîlauea magmas, though broadly tholeiitic, have relatively low silica contents, as indicated by the persistence of groundmass olivine in the subsolidus assemblages from Kîlauea Iki lava lake (Helz et al., 2014a), in contrast to most other Kîlauea lavas, which have no groundmass olivine (as in the prehistoric Makaopuhi lava lake; see Moore and Evans, 1967;

Evans and Moore, 1968). The $\mathrm{K}_{\mathrm{D}}$ results presented here are consistent with those of Roeder and Emslie (1970) for compositions with lower silica and higher $\mathrm{CaO}$ content.

Sample KP-20 from the 1960 Puna eruption (listed as F-12 in Table 2 of Murata and Richter, 1966), was the Kîlauea tholeiite used by Roeder and Emslie (1970). It is not a typical Kîlauea tholeiite, as it has a $\mathrm{CaO} / \mathrm{MgO}$ weight ratio of one at $\mathrm{MgO}=10$ weight percent. This is much lower than usually seen in Kîlauea basalts, as can be seen by looking at plots of $\mathrm{CaO}$ vs. $\mathrm{MgO}$ for lavas from the ongoing east rift eruption of Kîlauea (Thornber et al., 2015). In fact this ratio is like that of Mauna Loa basalts (Wright, 1971). The phase relations observed by Roeder and Emslie (1970) are similar to those found in Montierth et al.'s (1995) study of the melting relations of Mauna Loa basalts, and the olivine-melt $\mathrm{K}_{\mathrm{D}}$ value obtained for the Mauna Loa samples is 0.31, consistent with values Roeder and Emslie (1970) obtained on sample KP-20.

What of the vast bulk of Kilauea compositions that fall between the 1959 and KP-20 in terms of their $\mathrm{SiO}_{2}$ content and $\mathrm{CaO} / \mathrm{MgO}$ ratios? Extensive work on samples from the ongoing east rift eruption at Kîlauea show them as having $K_{D}$ values of $0.29-0.30$, as might be expected (Thornber, 2001; Thornber et al., 2015), from their intermediate compositions.

Given that the difference between $\mathrm{K}_{\mathrm{D}}=0.28$ and 0.31 is (barely) encompassed in the error brackets of \pm 0.03 originally assigned by Roeder and Emslie (1970), the question of the 
significance of the difference remains. This can be addressed by considering how much of an increase in the $\mathrm{Fe}^{+3} / \mathrm{Fe}^{\mathrm{T}}$ ratio would be required to shift the $\mathrm{K}_{\mathrm{D}}$ in the olivine-melt pairs shown in Fig. 5 to $K_{D}=0.30$. The answer is that it would require an increase of 0.06 (from 0.14 to 0.20 , for example), which is much larger than the analytical uncertainty in the $\mathrm{Fe}^{+3} / \mathrm{Fe}^{\mathrm{T}}$ ratio. Thus we conclude that the original 0.30 value is incompatible with the 1959 compositions, and that the value of 0.28 is to be preferred for them.

Nevertheless, it is very clear from the original study of Roeder and Emslie (1970), in which the phase relations of KP-20 were investigated over many orders of magnitude of oxygen fugacity, that $\mathrm{K}_{\mathrm{D}}$ is not sensitive to $\mathrm{Fe}^{+3} / \mathrm{Fe}^{\mathrm{T}}$ variations. The data in Fig. 6 are in basic agreement with that result. Consequently whatever the melt compositional control on $\mathrm{K}_{\mathrm{D}}$ may be, it is not sensitive to the $\mathrm{Fe}^{+3} / \mathrm{Fe}^{\mathrm{T}}$ ratio, and the offset in $\mathrm{K}_{\mathrm{D}}$ observed here cannot be attributed to varying methods in determining $\mathrm{Fe}^{+3} / \mathrm{Fe}^{\mathrm{T}}$ (or to second-order difficulties in determining $\mathrm{Fe}^{+3} / \mathrm{Fe}^{\mathrm{T}}$ ) in these or other studies.

\subsection{Controls on the Redox State of the 1959 Scoria: the Role of Sulfur}

Sulfur contents have been determined for all glasses chosen for $\mu$-XANES analysis, plus other glasses of interest in the same thin sections. The results (Fig. 9), show observed sulfur values for all individual points obtained for glasses in the eight scoria samples. Individual points are used here because the variation in sulfur in the embayment and interstitial glasses correlates strongly with the color of the glass (see color gradients in Fig. 3a and Fig. 3b.), and is analytically significant. Within each sample, melt inclusions in olivine have the highest sulfur contents, matrix glasses are generally lowest in sulfur, while interstitial and embayment glasses fall at intermediate levels. The available thin sections contain more examples of inclusion 
glasses and embayment or interstitial glasses than could be analyzed by $\mu$-XANES, due to spatial limitations imposed by the samples. Their sulfur contents are included here to show that the sulfur contents of inclusions and interstitial areas that were accessible to the beam are representative of larger populations.

There is no overall trend toward decreasing sulfur contents in glasses over the course of the 1959 eruption. The maximum sulfur content of the matrix glasses in Iki-2 is a bit higher than that in Iki-22 and Iki-3, perhaps reflecting the relatively low fountain heights at this stage of phase 1 (Table 4). Also early samples Iki-2 and Iki-22 contain rare blebs of immiscible sulfide liquid (Fig. 10), suggesting that the 1959E component was close to sulfide saturation at depth. It was no longer saturated by the time the samples were erupted, however, as the glasses surrounding these blebs have $\mathrm{S}<300 \mathrm{ppm}$, far below the level of saturation for basaltic liquids (Haughton et al., 1974; Jugo, 2009). Similar relict (metastable) sulfide blebs occur in other Kîlauea glasses (Helz and Wright, 1992), especially in the early stages of an eruption, presumably because degassing is less efficient prior to opening of the vent .

There is no other trend within each of the subsets of glasses distinguished in Fig. 9; it is as if each high-fountaining phase was a new eruption with a fresh supply of dissolved sulfur and other gases. This is consistent with the lava fountain heights observed by Richter et al. (1970), which remained high through phase 17 of the eruption. The fountain heights observed for the individual samples studied here (Table 4) show no falling off with time: the latest sample in the series (Iki-32) was erupted during the highest fountaining of the entire eruption (Richter et al., 1970). The lack of evolution in glass sulfur contents and fountain heights contrasts with the trend in olivine rim compositions (Fig. 2), which does show a progressive shift toward lower Fo contents and greater equilibration over the course of the eruption. 
The variation of $\mu$-XANES determinations with sulfur contents of their corresponding glasses is shown in Fig. 11.

There is a clear but modest dependence of the $\mathrm{Fe}^{+3} / \mathrm{Fe}^{\mathrm{T}}$ ratio on glass sulfur content, with glasses becoming more reduced as their sulfur content decreases. The melt inclusions in olivine have the highest $\mathrm{Fe}^{+3} / \mathrm{Fe}^{\mathrm{T}}$ values and the highest sulfur contents, while the embayment and interstitial glasses define the arrays at intermediate levels of both variables. The dependence is essentially the same in both the new (1959E) and stored (1959W) glasses. This contrasts with the olivine $\mathrm{K}_{\mathrm{D}}$ results (figs. 7 and 8), where there is a conspicuous difference between results for the 1959Eand 1959W-dominated samples.

Do the correlations between $\mathrm{Fe}^{+3} / \mathrm{Fe}^{\mathrm{T}}$ and glass sulfur content seen in Fig. 11 result purely from degassing, or have they been affected by rapid growth of olivine during quenching of the scoria? When the sulfur content of these glasses is plotted against their MgO contents ( $\mathrm{MgO}$ being the oxide most sensitive to olivine precipitation) we see in Fig. 12 that $\mathrm{MgO}$ does not vary as sulfur content increases in most samples:. The arrays of points are parallel to the vertical axis, as shown for glasses from Iki-5. The inclusion and interstitial glasses in Iki-22 and Iki-3, however, do lean toward slightly lower $\mathrm{MgO}$ contents than the matrix glasses in the same samples, consistent with minor overgrowth on adjacent olivine during the air quench. The amount of olivine required to increase the $\mathrm{MgO}$ of these confined glasses to match the average $\mathrm{MgO}$ content of the matrix glasses ranges from 0.76-2.46 weight percent (see example in Table 3). The Iki-22 and Iki-3 glass compositions used in Fig.s 7 and 11 are the corrected glasses.

\subsection{Other Influences on the Redox State of the 1959 Scoria}

As indicated in Fig. 11, there is a second process that affects the redox state of the 1959 
scoria glasses studied here, possibly stemming from cumulative interaction with magma that has drained back down the conduit at the end of each eruptive phase (Richter et al., 1970). This has been discussed, especially its effects on water content of the melts, by Wallace and Anderson (1998) and Sides et al. (2014). Here we see the effects on the $\mathrm{Fe}^{+3} / \mathrm{Fe}^{\mathrm{T}}$ ratios in the 1959 melts. These start out at high levels, and gradually decrease as sulfur is lost. However, the lowest values of $\mathrm{Fe}^{+3} / \mathrm{Fe}^{\mathrm{T}}$ are seen in matrix glasses from Iki-22 and Iki-3, with both averaging 0.122. Matrix glasses in other samples are slightly more oxidized, with average $\mathrm{Fe}^{+3} / \mathrm{Fe}^{\mathrm{T}}$ ratios for matrix glasses of 0.148 in Iki-10, 0.144 in Iki-26, and 0.137 in Iki-32, from phases 3, 10, and 15 respectively. This may reflect progressive dehydration of the magma, with some loss of $\mathrm{H}_{2}$ relative to $\mathrm{H}_{2} \mathrm{O}$, as discussed by Sato (1978).

In addition to this pervasive but mild oxidation seen in S-degassed matrix glasses, there is evidence for very late-stage interaction between the rims of scoria and the earth's atmosphere. Reddish, oxidized rims are seen on several of the XANES samples, but they are particularly conspicuous on sample Iki-26. A photomicrograph of area 2 in Iki-26, with the locations of all glass and olivine analyses, plus the $\mu$-XANES determinations, is shown in Fig. 13. The upper edge of the glass has a darkened, reddish rim. This rim is strongly oxidized $\left(\mathrm{Fe}^{+3} / \mathrm{Fe}^{\mathrm{T}}=0.628\right)$ and follows the shape of the scoria; it seems reasonable to suggest that this surface was exposed to air while the melt was still very hot and the thin oxidized rim is the result of that exposure.

This secondary oxidation does not extend through the whole body of the glass. Fig. 14 shows how the $\mathrm{Fe}^{+3} / \mathrm{Fe}^{\mathrm{T}}$ ratio varies with distance from the edge of the glass for the two traverses shown in Fig. 13 plus some data from area 1 on Iki-26. Ferric iron decreases very rapidly from 30 to 40 microns from the edge, declines slowly until a depth of $\sim 100$ microns in all three traverses, after which it appears to flatten out. 
How common are oxidized rims like that in Fig. 13? Of the samples investigated in this study, four (Iki-44, Iki-5, Iki-26 and Iki-32) have at least partial oxidized rims. Examination of 96 individual scoriae in available polished thin sections from 24 samples of the 1959 eruption shows that fifteen (including four in the XANES mounts) show at least local oxidation along glass rims similar to that illustrated here. Hence the process by which they formed is neither an automatic result of eruption nor extremely rare. These oxidized rims occur only on original, undulating glass exterior surfaces; where a piece of scoria has been broken, and the vesicular interior forms the edge in the thin section, no oxidation zone is observed. By contrast higher average $\mathrm{Fe}^{+3} / \mathrm{Fe}^{\mathrm{T}}$ contents in the matrix glasses in later samples, which may reflect gradual incorporation of air in the magma column as a result of lava drainback at the end of each highfountaining episode (Richter et al., 1970), is not confined to scoria rims, but has affected the body of the glass in the samples.

\subsection{Time Constraints on Processes Affecting the Redox State of the 1959 scoria}

The 1959 eruption was very closely observed, and the resulting extensive field observations (Richter et al., 1970) provide constraints on the timing of the processes discussed above. The sulfur degassing and concomitant reduction observed in Fig. 11 must have occurred

during ascent and eruption of the samples. Loss of sulfur as $\mathrm{SO}_{2}$ from most Kîlauea lavas begins only when magma ascends to pressures $\leq 100$ bars or 400 m depth (Dixon et al., 1991). However, studies of dissolved gases in inclusions from the 1959 scoria show that they record pressures between 0.5-2.0 kb (Anderson and Brown, 1993) and a recent study by Ferguson et al. (2013) suggests that degassing began at a depth of $\sim 3 \mathrm{~km}$ (or about 800 bars pressure) in this eruption. 
The fact that the semi-enclosed glasses have intermediate $\mathrm{Fe}^{+3} / \mathrm{Fe}^{\mathrm{T}}$ levels and sulfur contents implies that both variables were changing in parallel during the final stages of ascent of magma in the conduit, which was followed by fountaining, ejection and quenching of the samples. The successive phase 1 samples were ejected about 24 hours apart (Table 4), so it appears that the entire process of magma ascent, degassing and melt reduction documented here took place in no more than days and perhaps only a few hours. This is consistent with the earlier work of Wallace and Carmichael (1992), who inferred sulfur loss to be late in Kîlauea eruptions.

. The interaction of certain scoria with air, though not confined to later samples, is a very late process in the history of the individual scoria, and is even more tightly constrained in time. This process can only have occurred after fragmentation of the magma, as the occasional piece of scoria escaped from the sheath of magmatic gas that dominated within the fountain. The period from escape to quenching and deposition of the scoria could be no more than minutes to seconds. The absence of oxidation rinds on broken scoria surfaces implies that this process took place while the scoriae were in flight, before they were deposited on the ground.

The extreme time constraints on this process suggest that the zonation in the $\mathrm{Fe}^{+3} / \mathrm{Fe}^{\mathrm{T}}$ ratio seen is the result of diffusion of protons, rather than diffusion of oxygen, consistent with the findings of Gaillard et al. (2002) . Another relatively fast process, differential $\mathrm{H}_{2}$ loss (see Sato, 1978), should have produced rims on most scoriae, as all will have undergone loss of $\mathrm{H}_{2} \mathrm{O}$ and $\mathrm{H}_{2}$. The fact that only $10-15$ percent of the scoria fragments have such rims makes direct oxidation by contact with $\mathrm{O}_{2}$, via a mechanism of proton diffusion, a more likely process.

\subsection{Discussion of Redox Variations Observed}

\subsubsection{Sulfur Degassing at Kīlauea}


The most important process controlling the observed redox variation in the 1959 scoria is the extent of sulfur degassing, which these data show leads to reduction of $\mathrm{Fe}^{+3} / \mathrm{Fe}^{\mathrm{T}}$ ratios in the basaltic melts. Many previous studies at Kīlauea have hypothesized that sulfur loss has caused reduction of ferric iron in melts. The earliest of these (Anderson and Wright, 1972) was based on zoning of Fe-Ti oxide phenocrysts in the 1955 lavas. Subsequent studies (Carmichael and Ghiorso, 1986: Roeder et al., 2003, 2004) noted the contrast in oxidation state of submarine Kîlauea samples ( NNO conditions) vs. subaerial glasses (below QFM conditions, especially for samples from Kīlauea's east rift), and suggested that sulfur loss was responsible for the observed reduction. Gerlach $(1993,2004)$ argued on the basis of calculated oxygen fugacity of summit gas samples (Type A, presumably derived from reservoir-equilibrated magmas) vs. the estimated redox state of typical summit lavas (also equilibrated at upper-reservoir conditions, as discussed in Helz et al., 2014a) that degassing did not produce much change in the oxidation state of basaltic melts. The present study contributes a detailed look at the effect of very local sulfur degassing on in situ $\mathrm{Fe}^{+3} / \mathrm{Fe}^{\mathrm{T}}$ ratios. It is reasonably clear from Fig. 11 that sulfur loss does result in reduction, from $\mathrm{Fe}^{+3} / \mathrm{Fe}^{\mathrm{T}} \sim 0.17$ in the melt inclusions (1060-1360 ppm $\mathrm{S}$ ) to $\mathrm{Fe}^{+3} / \mathrm{Fe}^{\mathrm{T}} \sim 0.120-0.140$ in most matrix glasses (mostly $200 \mathrm{ppm}$ or less $\mathrm{S}$ ). The plain inference is that Kîlauea lavas and glasses with extremely low $\mathrm{Fe}^{+3} / \mathrm{Fe}^{\mathrm{T}}$ ratios are not the most pristine material, but are instead the most thoroughly degassed. Thus it makes sense that the Pu'u O'o samples of Roeder et al. $(2003,2004)$ are consistently more reduced than the broader data set of Carmichael and Ghiorso (1986), which contain lavas from Kîlauea's summit as well as east rift lavas (see e.g. Gerlach (1993) model for degassing at Kîlauea). Our data suggest that the melts originally had an $\mathrm{Fe}^{+3} / \mathrm{Fe}^{\mathrm{T}}$ ratio $\geq 0.175$, corresponding to an oxygen fugacity $0.4 \log$ units about the fayalite-magnetite-fayalite (FMQ) buffer (Frost, 1991) at 1 atmosphere and $1200^{\circ} \mathrm{C}$, similar 
to to that seen by Gerlach (1993) in his Type A gases.

There are many possible sulfur species that may be lost to the vapor phase, and a great many different reactions can be written to describe them (see e.g., Gerlach, 1993; Jugo et al., 2010; de Moor et al., 2015; Moussallam et al., 2016). However we observe a reduction correlated with decrease in dissolved sulfur, so the relevant reaction is one by which sulfur degassing causes reduction of $\mathrm{Fe}^{+3}$ in the melt. This can be written:

$$
(\mathrm{FeS})_{\text {melt }}+\left(\mathrm{Fe}_{2} \mathrm{O}_{3}\right)_{\text {melt }}+\left(\mathrm{O}_{2}\right)_{\text {melt }} \rightarrow 3(\mathrm{FeO})_{\text {melt }}+\left(\mathrm{SO}_{2}\right)_{\text {gas }}
$$

In order for the reaction to move consistently to the right, it is necessary (1) that the melt contain sulfur as sulfide $\left(\mathrm{S}^{-2}\right)$ and (2) that the $\mathrm{SO}_{2}$ so produced partition into a vapor phase and escape from the system. For the 1959 lavas, the presence of immiscible sulfide liquid, rarely in the matrix glasses (Fig. 10) but more commonly in melt inclusions in olivine (Helz, 1987) suggests that a significant fraction of the sulfur present in the 1959 melts is sulfide. The sporadic occurrence of sulfide droplets in other Kîlauea lavas (Helz and Wright, 1992) suggest that this is generally true at Kīlauea. The overall pattern of sulfur loss and reduction (Fig. 11) is consistent with the process occurring at low pressures, as the magma began to vesiculate.

An important question is: are the amounts of sulfur lost and the extent of reduction observed compatible with each other? Using data from inclusion glasses vs. adjacent matrix glasses in Appendix A, we calculate as follows:

\begin{tabular}{|c|c|c|c|c|}
\hline & Iki-3 & Iki-44 & Iki-5 & Iki-32 \\
\hline Decrease in $\mathrm{S}$ in glass (moles/100 grams) & 0.0038 & 0.0037 & 0.0033 & 0.0033 \\
\hline Times 6 electrons per $\mathrm{S}$ ion & 0.023 & 0.023 & 0.020 & 0.020 \\
\hline Decrease in $\mathrm{Fe}^{+3}$ (moles/100 grams) & 0.009 & 0.008 & 0.005 & 0.002 \\
\hline
\end{tabular}

From this it appears that the maximum number of electrons available for reduction of $\mathrm{Fe}^{+3}$ is 
more than needed. This in turn suggests that some of the sulfur lost (for it has been lost extensively from the matrix glasses) was not lost by the reaction shown above.

Modeling by Gaillard, Scaillet and co-workers shows that sulfur species partitioning is extremely sensitive to pressure; specifically, as pressure increases, more of the sulfur will be lost as $\mathrm{H}_{2} \mathrm{~S}$ rather than $\mathrm{SO}_{2}$, with $\mathrm{H}_{2} \mathrm{~S}$ strongly dominant by pressures of 1000 bars (e.g. Scaillet et al., 1998; Gaillard and Scaillet, 2009). Exsolution of $\mathrm{H}_{2} \mathrm{~S}$ from a melt in which $\mathrm{S}^{-2}$ is the dominant species should not affect the redox state of the melt. If the degassing of the 1959 melts begins at higher pressures than in most Kîlauea eruptions as has been suggested by Anderson and Brown (1993), Ferguson et al. (2013) and Tuohy et al. (2016), it seems likely that early sulfur degassing of these melts would have been by $\mathrm{H}_{2} \mathrm{~S}$ partitioning into a $\mathrm{CO}_{2}$-rich vapor phase, with no change in redox state. This in turn implies that the reduction signal seen has been produced by degassing at higher levels (Wallace and Carmichael, 1992), with much of it post-fragmentation as suggested by the relatively high $\mathrm{S}$ contents retained in quenched interstitial glasses.

However, if we use the data of Carroll and Rutherford (1988) and Jugo et al. (2010) on sulfur speciation in the melt, we estimate that about $15 \%$ of the sulfur is present as sulfate $\left(\mathrm{S}^{+6}\right)$ in the inclusions but that there is less than $5 \%$ sulfate in the matrix glasses. The sulfur in the melt is dominantly sulfide $\left(\mathrm{S}^{-2}\right)$ in both cases. The shift in $\mathrm{S}^{+6} / \mathrm{S}^{-2}$ is also a redox reaction and can be written as follows:

$$
\left(\mathrm{SO}_{3}\right)_{\mathrm{melt}}+2(\mathrm{FeO})_{\mathrm{melt}}=\left(\mathrm{SO}_{2}\right)_{\mathrm{gas}}+\left(\mathrm{Fe}_{2} \mathrm{O}_{3}\right)_{\mathrm{melt}}
$$

As $\mathrm{SO}_{2}$ is generated in moving to the right, this reaction must also be restricted to fairly low pressures and run in tandem with equation (3). For the six $\mathrm{Fe}^{+3}$ ions that can be reduced by equation (3), this second reaction causes two Fe+2 ions to be oxidized. The net effect will still be reduction, as seen in Fig. 11. Also there is some excess $\mathrm{S}$ loss beyond that needed to 
produce the observed reduction, so some deeper loss of $\mathrm{H}_{2} \mathrm{~S}$ is still indicated.

A recent $\mu$-XANES study of matrix glasses and inclusions in olivines found in summit spatter from Kīlauea (Moussallam et al., 2016) shows a similar mild reduction trend, covering much the same range of sulfur contents and $\mathrm{Fe}^{+3} / \mathrm{Fe}^{\mathrm{T}}$ ratios. These samples have differentiated bulk, melt $(\mathrm{MgO}=7.5-6.2 \%)$ and fayalitic olivine (Fo F2.5-77.6 $)$ compositions, so are characteristic of material from the shallowest part of Kîlauea's magma reservoir (Helz et al., 2014a). This is a magma body determined by microgravity studies to lie at $\sim 1 \mathrm{~km}$ depth (Johnson et al., 2010), which corresponds to a pressure of 200-300 bars. The reduction trends, compared in Fig. 15, are remarkably similar. Thus the degassing processes should be similar, in spite of the substantial differences in phase compositions between the summit spatter and the 1959 scoria.

One important difference between Moussallam et al (2016) and the present study is that the documented $\mathrm{S}$ loss and decrease in the $\mathrm{Fe}^{+3} / \mathrm{Fe}^{\mathrm{T}}$ ratio in the summit spatter is observed for glasses included in olivine, showing that the magma body was undergoing $\mathrm{SO}_{2}$ loss in situ, prior to eruption. In the 1959 scoria, by contrast, melt inclusions in olivine show relatively little shift in $\mathrm{S}$ content and $\mathrm{Fe}^{+3} / \mathrm{Fe}^{\mathrm{T}}$ ratio, consistent with their having formed at depths too great for significant $\mathrm{SO}_{2}$ loss. In the samples studied here, the shifts are observed largely in the interstitial and embayment glasses, suggesting that the changes occurred in the rising magma column, and mostly after fragmentation of the magma.

\subsubsection{Sulfur degassing in other systems}

The development of the $\mu$-XANES technique, which allows in situ determination of $\mathrm{Fe}^{+3} / \mathrm{Fe}^{\mathrm{T}}$ ratios, has resulted in an increasing number of studies examining the effect of 
degassing on their redox state. Kelley and Cottrell (2012), who studied melt inclusions in olivines from Agrigan volcano in the Marianas, were able to track changes in melt compositions, and found a correlation between magmatic differentiation, lower sulfur contents and decreasing $\mathrm{Fe}^{+3} / \mathrm{Fe}^{\mathrm{T}}$ ratios. The sulfur and $\mathrm{Fe}^{+3} / \mathrm{Fe}^{\mathrm{T}}$ levels in the Agrigan glasses are both higher than seen in the 1959 scoria, but the overall trend of those data is similar to that in Fig. 11.

Another study by Moussallam et al. (2014) used XANES to evaluate both the $\mathrm{Fe}^{+3} / \mathrm{Fe}^{\mathrm{T}}$ ratio in glass inclusions in olivine from Mt. Erebus that ranged in composition from basanite to phonolite. Their results showed that the melts are consistently oxidized $\left(\mathrm{Fe}^{+3} / \mathrm{Fe}^{\mathrm{T}}=0.30-0.40\right)$ at higher pressures, but become more reduced (0.15-0.25) and have lower sulfur contents at lower pressures.

At Mt. Erebus the pressures calculated for the inclusions suggest that there was a $\mathrm{CO}_{2^{-}}$ rich vapor phase present, as would be expected from the extremely alkalic melt compositions observed. This vapor phase presumably made it possible for sulfur degassing to begin at pressures up to 1000 bars (Fig. 5a in Moussallam et al., 2014), similar to the pressures suggested for the 1959 Kîlauea eruption, as discussed above (Anderson and Brown, 1993; Ferguson et al., 2013; Tuohy et al., 2016). Overall, evidence from XANES studies to date suggests that sulfur degassing can change the redox state of lavas. However, suites of melt inclusions from three additional Mariana volcanoes (Brounce et al., 2014) as well as Erta Ale (Ethiopia) and Masaya (Nicaragua) (de Moor et al., 2013) showed no correlation between melt sulfur concentration and $\mathrm{Fe}^{+3} / \mathrm{Fe}^{\mathrm{T}}$ levels, indicating that the relationship observed at Kîlauea, Agrigan, and Erebus is not universal. As de Moor et al. (2013) points out the strong pressure dependence of sulfur speciation suggests that variable depth of origin for the various volcanic suites may explain why 
the effect of sulfur degassing on melt redox state is so variable.

Other volatiles besides sulfur could also have an effect. Carmichael and Ghiorso (1986) have already suggested that Kîlauea lavas may start out more reduced than $\mathrm{Fe}^{+3} / \mathrm{Fe}^{\mathrm{T}}$ levels of 0.175 seen in the 1959 inclusions, based on wet chemical analyses of samples of lavas (not glasses) from the deepest part of Kīlauea's submarine east rift (data from Moore, 1965). This is not definitive, however, as those deepest samples have traces of carbonaceous material of uncertain origin (Carmichael and Ghiorso, 1986), but it does emphasize the need to be able to reconstruct all stages of degassing, in order to reconstruct the redox history of magma at depth and estimate redox conditions in the mantle.

\section{$\underline{8.1 \text { Summary }}$}

This paper presents new data on eight scoria samples (five from phase 1 and 3 from later phases) from the 1959 summit eruption of Kîlauea Volcano, including $78 \mu$-XANES analyses of individual glass points, together with electron microprobe analyses of those glasses and the nearest adjacent olivines. The suite of locations analyzed includes four melt glass inclusions, plus four areas of interstitial and embayment glasses in olivine crystals and crystal clusters. These data allow direct calculation of $\mathrm{K}_{\mathrm{D}}$ values for the exchange of $\mathrm{Mg}$ and $\mathrm{Fe}^{+2}$ between olivine and melt. Results show that:

(1) The olivine-melt $K_{D}$ values in the two best equilibrated samples (Iki-26, Iki-32 from late in the eruption) cluster around $0.280 \pm 0.03$, offset from the $0.30 \pm 0.03$ reported by Roeder and Emslie (1970). This may reflect the low $\mathrm{SiO}_{2}$ content in the 1959 lavas, as similar $\mathrm{K}_{\mathrm{D}}$ values were observed for low- $\mathrm{SiO}_{2}$ bulk compositions in that original study, as discussed by Matzen et al. (2011).

(2) Olivine-melt $K_{D}$ 's for phase 1 samples rich in the $1959 \mathrm{E}$ (juvenile) component of the 
eruption show a broader distribution, centering around 0.26-0.27, suggesting that these samples are less well-equilibrated than the late samples (Iki-26, Iki-32). $\mathrm{K}_{\mathrm{D}}$ values for phase 1 samples rich in the 1959W (stored) component show pervasive lack of equilibration, consistent with most of the olivine originating from the 1959E magmatic component of the eruption.

(3) Sulfur levels in scoria glasses investigated in this study do not change over the course of the eruption, with glasses in late samples having ranges in sulfur for inclusions, interstitial areas and matrix glasses similar to those in the phase 1 samples. However, sulfur degassing is progressive within samples, as sulfur decreases from 1060-1400 ppm for melt included in olivine, to $<300 \mathrm{ppm}$ in matrix glasses.

(4) Sulfur loss within the scoriae is linearly correlated with a decrease in the $\mathrm{Fe}^{+3} / \mathrm{Fe}^{\mathrm{T}}$ ratio in the melt; this is most clearly documented in the phase 1 samples (Fig. 11). The slopes of the lines are parallel for the 1959E and 1959W samples, showing that degassing behavior was independent of the identity of the magmatic component.

(5) The 1959 Kîlauea melts originally had an $\mathrm{Fe}^{+3} / \mathrm{Fe}^{\mathrm{T}}$ ratio $\geq 0.175$, corresponding to an oxygen fugacity $0.4 \log$ units about the fayalite-magnetite-quartz (FMQ) buffer (Frost, 1991) at 1 atmosphere and $1200^{\circ} \mathrm{C}$.

(6) Oxidized rims having gradients in $\mathrm{Fe}^{+3} / \mathrm{Fe}^{\mathrm{T}}$ ratios of 0.145 to 0.628 over distances of 100150 microns occur in visibly reddened glass bordering some scoria. Such rims, present on $10-15 \%$ of scoria examined to date, appear to be produced by very late interaction between hot melt and oxygen in the surrounding air.

(7) Field observations on the 1959 eruption constrain the time available for these processes to occur. Sulfur degassing (and the resulting $\mathrm{Fe}^{+3} / \mathrm{Fe}^{\mathrm{T}}$ reduction) took place over hours to 
days, while the oxidized rims on scoria must have been produced over minutes to seconds.

The results of this study demonstrate that changes in $\mathrm{Fe}^{+3} / \mathrm{Fe}^{\mathrm{T}}$ ratios, as tracked by $\mu$ XANES, can be extremely fast. By contrast olivine-melt re-equilibration is somewhat slower; thus under conditions of changing $\mathrm{Fe}^{+3} / \mathrm{Fe}^{\mathrm{T}}$, olivine best tracks redox changes where olivine and melt are already close to equilibrium. Examples here include olivine-melt pairs in the later samples and for olivine indigenous to the 1959E melts. Significant re-equilibration over the course of the five week-long eruption suggests that disequilibrium in early samples is syneruptive, i.e., is the result of very recent mixing during staging of the magmatic components.

\subsection{Conclusions}

Several broad conclusions can be drawn from this study. The first is that degassing can affect the $\mathrm{Fe}^{+3} / \mathrm{Fe}^{\mathrm{T}}$ ratio in volcanic melts, so that deciphering the redox history of magmas will require understanding all stages of degassing that the magmas have undergone before and during eruption. A related conclusion is that the 1959 magmas probably had $\mathrm{Fe}^{+3} / \mathrm{Fe}^{\mathrm{T}} \geq 0.175$ at depth (relative to a global average for MORB of $0.15 \pm 0.01$. Whether this is true for Hawaiian magmas in general remains to be established.

We also show the potential for spatially coupled XANES and electron microprobe analyses to refine estimates of $K_{D}$ in natural systems. At Kilauea Iki, the olivine-melt $K_{D}$ values cluster around $0.280 \pm 0.03$. Finally, this study shows that $\mu$-XANES can provide detailed insight into very rapid processes that occur in melts during ascent of magma prior to eruption, during fountaining and during subsequent ejection and quenching. Other geothermometers and oxybarometers may not re-equilibrate as quickly as the $\mathrm{Fe}^{+3} / \mathrm{Fe}^{\mathrm{T}}$ ratio can, so that applying 
multiple systems to subaerially erupted lavas may appear to give inconsistent results, owing to varying rates of re-equilibration in the various systems. 


\section{$\underline{\text { Acknowledgements }}$}

We wish to acknowledge helpful reviews by Carl Thornber (USGS, Cascades Volcano

Observatory, Vancouver WA), J.M. de Moor (Observatorio Vulcanologico y Sismologico de Costa Rica, Universidad National, Heredia, Costa Rica) and Malcolm J. Rutherford (Brown University, Provicence, RI).. The assistance of H. Belkin (USGS, Reston, VA) in obtaining the electron microprobe data was greatly appreciated. We appreciate the assistance of Leslie Hale and Tim Gooding, and the use of samples from the National Rock and Ore Collection at the Smithsonian. Tony Lanzirotti, Sue Wirick, and Bill Rao assisted in all aspects of beamline operations and analysis related to the collection of XANES data. Any use of trade, firm, or product names is for descriptive purposes only and does not imply endorsement by the U.S. Government.” Access to the National Synchrotron Light Source, Brookhaven National Laboratory was supported by the US Department of Energy, Office of Science, Office of Basic Energy Sciences, under Contract No. DE-AC02-98CH10886. We acknowledge support from NSF awards EAR-0841108 (KK) and EAR-0841006 (EC). 


\section{$\underline{\text { References Cited }}$}

Anderson, A.T., Jr. and Brown, G. G., 1993, $\mathrm{CO}_{2}$ contents and formation pressures of some Kilauean melt inclusions: American Mineralogist, v. 78, p. 794-803.

Anderson, A.T., Jr., and Wright, T.L., 1972, Phenocrysts and glass inclusions and their bearing on oxidation and mixing of basaltic magmas, Kilauea volcano, Hawaii: American Mineralogist, v. 57, nos. 1-2, p. 188-216.

Berry, A. J., O'Neill, H. S., Jayasuriya, K. D., Campbell, S. J. and Foran, G. J., 2003. XANES calibrations for the oxidation state of iron in a silicate glass: American Mineralogist, v. 88, p. 967-977.

Brounce, M., Kelley, K.A. and Cottrell, E., 2014, $\mathrm{Fe}^{3+} / \Sigma \mathrm{Fe}$ variations in Mariana arc basalts and primary $\mathrm{fO}_{2}$ for the mantle wedge: Journal of Petrology, v. 55, p. 2513-2536, doi:1093/petrology/egu065.

Carmichael, I.S.E. and Ghiorso, M.S., 1986, Oxidation-reduction relations in basic magma: a case for homogeneous equilibria: Earth and Planetary Science Letters. V. 78, p. 200-210.

Carroll, M.R. and Rutherford, M J., 1988, Sulfur speciation in hydrous experimental glasses of varying oxidation state: Results from measured wavelength shifts of sulfur X-rays: American Mineralogist v. 73, p. 845-849.Cottrell, E., Kelley, K.A., Lanzirotti, A., and Fischer, R.A., 2009, High-precision determination of iron oxidation state in silicate glasses using XANES: Chemical Geology v. 268, p. 167-179.

Cottrell, E., and Kelley, K.A., 2011, The oxidation state of Fe in MORB glasses and the oxygen fugacity of the upper mantle: Earth and Planetary Science Letters, v. 305, p. 270-282.

de Moor, J.M., Fischer, T.P., Sharp, Z.D., King, P.L., Wilke, M., Botcharnikov, R. E., Cottrell, E., Zelenski, M., Marty, B., Klimm, K., Rivard, C., Ayalew, D., Ramirez, C., 2013. Sulfur 
degassing at Erta Ale (Ethiopia) and Masaya (Nicaragua): Implications for degassing processes and oxygen fugacities of basaltic systems. Geochemistry, Geophysics, Geosystems 14, doi:10.1002/ggge.20255.

Dixon, J. E., Clague, D. A., and Stolper, E. M., 1991. Degassing history of water, sulfur, and carbon in submarine lavas from Kilauea Volcano, Hawaii: Journal of Geology, v. 99. no. 3, p. 371-394, doi:10.1086/629501.

Eaton, J.P., and Murata, K.J., 1960, How volcanoes grow: Science, v. 132, no. 3432, p. 925-938, doi:10.1126/science.132.3432.925.

Eaton, J.P., Richter, D.H., and Krivoy, H.L., 1987, Cycling of magma between the summit reservoir and Kilauea Iki lava lake during the 1959 eruption of Kilauea Volcano, chap. 48 of Decker, R.W., Wright, T.L., and Stauffer, P.H., eds., Volcanism in Hawaii: U.S. Geological Survey Professional Paper 1350, v. 2, p. 1307-1335.

Evans, B.W., and Moore, J.G., 1968, Mineralogy as a function of depth in the prehistoric Makaopuhi tholeiitic lava lake, Hawaii: Contributions to Mineralogy and Petrology, v. 17, no. 2, p. $85-115$.

Ferguson, D. J., Plank, T. A., Hauri, E. H., Houghton, B. F., Gonnermann, H. M., Swanson, D. A. and Blaser, A P., 2013, Comparing eruptions of varying intensity at Kỉlauea via melt inclusion analysis. Abstract V32F-07, presented at 2013 Fall Meeting, AGU, San Francisco, Calif., 9-13 December 2013.

Frost, B.R., ed., 1991. Introduction of Oxygen Fugacity and its Petrologic Importance. BookCrafters, Chelsea, MI, v. 25, p. 1-9.

Gaillard, F. Scaillet, B. Pichavant, M., 2002, Kinetics of iron oxidation-reduction in hydrous silicic melts. American Mineralogist v. 87, p. 829-837. 
Gaillard, F. \& Scaillet, B., 2009, The sulfur content of volcanic gases on Mars. Earth and Planetary Science Letters, v. 279, p. 34-43.

Gerlach, T. M., 1993, Oxygen buffering of Kilauea volcanic gases and the oxygen fugacity of Kilauea basalt: Geochimica et Cosmochimica Acta v. 57, no. 4, p. 795-814, doi:10.1016/0016-7037(93)90169-W.

Gerlach, T. M., 2004, Comment on paper: "Morphology and compositions of spinel in Pu'u O'o lava (1996-1998), Kilauea volcano, Hawaii” -- enigmatic discrepancies between lava and gas-based $\mathrm{f}_{\mathrm{O} 2}$ determinations of Pu'u O'o lava: Journal of Volcanology and Geothermal Research, v. 134, p. 241-244.

Haughton, D. R., Roeder, P.L., and Skinner, B.J., 1974, Solubility of Sulfur in Mafic Magmas: Economic Geology, v. 69, p. 451-467.Helz, R.T., 1987. Diverse olivine types in lavas of the 1959 eruption of Kilauea Volcano, and their bearing on eruption dynamics: in Decker, R.W., Wright, T.L. and Stauffer, P.H., eds., Volcanism in Hawaii: U.S. Geological Survey Professional Paper 1350, 691-722.

Helz, R.T. and Thornber, C.R., 1987. Geothermometry of Kilauea Iki lava lake, Hawaii: Bulletin of Volcanology, v. 49, 651-668.

Helz, R.T. and Wright, T.L., 1992, Differentiation and magma mixing on Kilauea's east rift zone: A further look at the eruptions of 1955 and 1960. Part I. The later 1955 lavas. Bulletin of Volcanology, v. 54, pp. 361-384.

Helz, R.T., 2009a, Processes active in mafic magma chambers; the example of Kîlauea Iki lava lake, Hawaii: Lithos, v. 111, nos. 1-2, p. 37-46, with electronic supplement, doi:10.1016/j.lithos.2008.11.007. 
Helz, R.T., 2009b, Reduction of basaltic melt during near-surface evolution of $\mathrm{SO}_{2}$ : A possible example from Kīlauea. 2009 Portland GSA Annual Meeting, Paper no. 248-21.

Helz, R. T., Clague, D.A., Sisson, T. W., and Thornber, C. R., 2014a, Petrologic Insights into Basaltic Volcanism at Historically Active Hawaiian Volcanoes: in eds. Poland and Kauahikaua, Characteristics of Hawaiian Volcanoes, USGS Professional Paper 1801, Chapter 6, pp. 1-55, http://dx.doi.org/10.3133/pp1801.

Helz, R.T., Clague, D.A., Mastin, L. G. and Rose, R. T, 2014b, Electron Microprobe Analyses of Glasses from Kīlauea Tephra Units, Kīlauea Volcano, Hawaii: U.S. Geological Survey Open File Report 2014-1090, 24 p. plus 2 appendices in separate files, http://dx.doi.org/10.3133/ofr20141090.

Helz, R.T., Cottrell, E., Kelley, K. A., and Brounce, M. N., 2014c, Redox history of the 1959 summit eruption of Kīlauea determined by XANES analysis of glassy scoria: Goldschmidt2014 Abstracts, 962.

Helz, R.T., Cottrell, E., Kelley, K. A., and Brounce, M. N., 2015, Olivine-melt equilibration and redox relationships in scoria from the 1959 eruption of Kîlauea Volcano, Hawaii: GSA abstract 76-4, presented at the 2015 GSA Annual Meeting, Baltimore, MD, November 2015. Hirschmann, M., Zhang, H. and Cottrell, E., 2015, Revised Mossbauer Calibration for $\mathrm{Fe}^{+3} / \mathrm{Fe}^{\mathrm{T}}$ of XANES Basalt Standards: Implications for MORB. Abstract V31D-3049, presented at 2015 Fall Meeting, AGU, San Francisco, Calif., 14-18, December 2015.

Johnson, D. J., Eggers, A.A., Bagnardi, M., Battaglia, M., Poland M.P., and Miklius, A., 2010, Shallow magma accumulation at Kīlauea Volcano, Hawaii, revealed by microgravity surveys: Geology, v. 38, p. 1139-1142, doi: 10.1130/G31323.1. 
Jugo, P. J., 2009, Sulfur content at sulfide saturation in oxidized magmas: Bulletin of the Geological Society of America, v. 37, p. 415-418.

Jugo, P.J., Wilke, M. and Botcharnikov, R. E., 2010, Sulfur K-edge XANES analysis of natural and synthetic basaltic glasses: Implications for $\mathrm{S}$ speciation and $\mathrm{S}$ content as function of oxygen fugacity: Geochimica et Cosmochimica Acta, v. 74, p. 5926-5938.

Kelley, K.A., and Cottrell E., 2012, The influence of magmatic differentiation on the oxidation state of Fe in a basaltic arc magma: Earth and Planetary Science Letters, v. 329-330, p. 109121.

Matzen, A.K., Baker, M.B., Beckett, J.R., and Stolper, E.M., 2011. Fe-Mg Partitioning between Olivine and High-magnesium Melts and the Nature of Hawaiian Parental Liquids: Journal of Petrology, v. 52 (7-8), p. 1243-1263, and electronic supplement.

Montierth, C., Johnston, A. D. and Cashman, K. V., 1995, An Empirical Glass-CompositionBased Geothermometer for Mauna Loa Lavas: in Rhodes, J. M and Lockwood, J. P., eds., Mauna Loa Revealed: AGU Geophysical Monograph 92, pp. 207-217.

Moore, J.G., 1965, Petrology of Deep-Sea Basalt near Hawaii: American Journal of Science v. 263, p. 40-52.

Moore, J.G., and Evans, B.W., 1967, The role of olivine in the crystallization of the prehistoric Makaopuhi tholeiitic lava lake, Hawaii: Contributions to Mineralogy and Petrology, v. 15, no. 3, p. 202-223, doi:10.1007/BF01185342.

Moussallam,Y., Oppenheimer, C., Scaillet, B., Gaillard, F., Kyle, P, Peters, N., Hartley, M., Berlo, K. and Donovan, A., 2014, Tracking the changing oxidation state of Erebus magmas, from mantle to surface, driven by magma ascent and degassing: Earth and Planetary Science Letters, v. 393, p. 200-209. 
Moussallam, Y., Edmonds, M., Scaillet, B., Peters, N., Gennaro, E., Sides, I. and Oppenheimer, C., 2016, The impact of degassing on the oxidation state of basaltic magmas: A case study of Kīlauea volcano: Earth and Planetary Science Letters, v. 450, p. 317-325.

Murata, K.J. and Richter, D. H., 1966. Chemistry of the lavas of the 1959-60 eruption of Kīlauea Volcano, Hawaii. U.S. Geological Survey Professional Paper 537-A, 26 pp.Richter, D. H., Eaton, J. P., Murata, J., Ault, W. U., and Krivoy, H. L., 1970. Chronological narrative of the 1959-60 eruption of Kilauea Volcano, Hawaii: U.S. Geological Survey Professional Paper 537-E, 73 pp.

Roeder, P.L. and Emslie, R.F., 1970. Olivine-Liquid Equilibrium: Contributions to Mineralogy and Petrology, v. 29, p. 275-289.

Roeder, P.L., Thornber C., Poustovetov, A. and Grant, A., 2003, Morphology and composition of spinel in Pu'u O'o lava (1996-1998), Kīlauea volcano, Hawaii: Journal of Volcanology and Geothermal Research, v. 123, p. 245-265.

Roeder, P.L., Thornber, C. and Grant, A., 2004, Reply to comment on paper: "Morphology and composition of spinel in Pu'u O'o lava (1996-1998), Kīlauea volcano, Hawaii” - enigmatic discrepancies between lava and gas-based fO2 determinations of Pu'u O'o lavas: Journal of Volcanology and Geothermal Research, v. 134, p. 245-248.

Ruffoni, M. P. and Pettifer, R.F., 2006. Calibration of XANES spectra from dispersive XAS beamline: Journal Synchrotron Radiation, v. 13. P. 489-493.

Sato, M., 1978, Oygen fucagicty of basaltic magmas and the role of gas-forming elements: Geophysical Research Letters, v. 5, p. 447-449.

Scaillet, B. Clemente, B., Evans, B.W., Pichavant, M., 1998, Redox control of sulfur degassing in silicic magmas. Journal of Geophysical Research: Solid Earth v. 103, p. 23937. 
Schwindinger, K.R., and Anderson, A. T., Jr., 1989, Synneusis of Kilauea Iki olivines:

Contributions to Mineralogy and Petrology, 103, 187-198.

Sides, I., Edmonds, M., Maclennan, J., Houghton B.F., Swanson, D.A. and Steele-Macinnes, M.J., 2014, Magma mixing and high fountaining during the 1959 Kîlauea Iki eruption, Hawaii: Earth and Planetary Science Letters, v. 400, p. 102-112.

Thornber, Carl R., 2001, Olivine-liquid relations of lava erupted by Kilauea Volcano from 19941998: Implications for shallow magmatic processes associated with the ongoing east rift zone eruption; In "Phase equilibria in basaltic systems"(Canil, D., Jamieson H., and Martin R., eds), Canadian Mineralogist, Vol. 39, p.239-266 doi:10.2113/gscamin.39.2.239

Thornber, C. R., Orr, T.R., Heliker, C. and Hoblitt, R. P., 2015, Petrologic Testament to Changes in Shallow Magma Storage Transport During 30+ Years of Recharge and Eruption at Kîlauea Volcano, Hawaii: chap 8 of Carey, R. J., V. Cayol, M. P. Poland, and D. Weis (eds.), Hawaiian Volcanoes: From Source to Surface, American Geophysical Union Monograph 208, pp 147-188, doi:10.1002/978111882079.ch8.

Tuohy, R.M., Wallace, P. J., Loewen, M.W., Swanson, D.A., and Kent, A.J.R, 2016, Magma transport and olivine crystallization depths in Kilauea's east rift zone inferred from experimentally rehomogenized melt linclusions: Geochimica et Cosmochimica Acta, v. 185 , p. $232-250$.

Wallace, P. and Carmichael, I.S.E., 1992, Sulfur in basaltic magmas: Geochimica et Cosmochimica Acta, v. 56, p. 1863-1874. 
Wallace, P. and Anderson, A.T. Jr., 1998, Effects of eruption and lava drainback on the $\mathrm{H}_{2} \mathrm{O}$ contents of basaltic magmas at Kilauea Volcano: Bulletin of Volcanology, v. 59, p. 327-344.

Wilke, M., Partzsch, G. M., Bernhardt, R. and Lattard, D., 2005. Determination of the iron oxidation state in basaltic glasses using XANES at the K-edge: Chemical Geology, v. 220, p. 143-161.

Wright, T.L., 1971, Chemistry of Kilauea and Mauna Loa lava in space and time: U.S. Geological Survey Professional Paper 735, 49 pp.

Wright, T. L., 1973. Magma mixing as illustrated by the 1959 eruption, Kilauea Volcano, Hawaii: Geological Society of America Bulletin 84, 849-858. 
Figure 1. MgO content of glasses in scoria samples from the $1959 \mathrm{~K} 1$ lauea eruption. The samples are plotted in chronological sequence, each with the number of its eruptive phase indicated below. Longer pauses in the eruption (see Richter and others, 1970) are marked by blank positions. Data for 22 scoria samples are in Helz (1987, 2009a); data for two samples (Iki-5, Iki-25) are previously unpublished. In some samples, there is a range of glass $\mathrm{MgO}$ contents. Using the endmember proportions calculated by Wright (1973), the samples fall into three groups: those with $31-70 \%$ of the 1959E component (red circles), those with $88-100 \%$ of the $1959 \mathrm{~W}$ component (blue triangles) and later hybrids (phases 516 , green inverted triangles), mostly with $\sim 20 \%$ of the $1959 \mathrm{E}$ component.

Figure 2a. Composition of euhedral rims on olivine phenocrysts for 19 scoria samples from the 1959 summit eruption of Kîlauea, with the samples plotted in chronological sequence as in figure 1 (Helz, 1987, 2009b) and unpublished data. Phenocrysts are defined here as crystals $\geq 1 \mathrm{~mm}$ in length. Three samples (Iki-1, Iki-58, Iki-9) have no phenocrysts, so are not included here. Vertical dashed lines connect compositions within individual scoria samples. The maximum Fo rim composition found at different stages of the eruption, marked by heavy lines, shows an irregularly step-wise decline with time.

Figure $2 \mathrm{~b}$. Composition of microphenocrystic and groundmass olivines from most of the scoria samples included in Figure 2a, plus Iki-1, Iki-58 (phase 1, position 1) and Iki-9 (phase 3, position 15$)$. The latter three samples contain only smaller $(<1 \mathrm{~mm})$ olivine crystals. Compositions are from Helz (1987, 2009b) plus some unpublished data. The vertical dashed lines emphasize the sizeable range in composition found within many scoria samples for the smaller olivines.

Figure 3a. Small $(<1 \mathrm{~mm})$ olivines in vesicular glass in sample Iki-3, area 1. Note darker glass in embayed olivine (upper left of photomicrograph). Figure 3b. Cluster of euhderal olivines in vesicular glass in sample Iki-5, area 1, with inclusion, zoned interstitial glass. Figure 3c. Cluster of euhedral olivines in vesicular glass in sample Iki-32, area 1. Melt inclusion in the largest olivine contains sulfide bleb, vapor bubble.

Figure 4. $\mathrm{Fe}^{+3} / \mathrm{Fe}^{\mathrm{T}}$ ratios, as determined using $\mu$-XANES, observed in the 1959 scoria glasses. The calibration used is the revision of Hirschmann and others (2015), which also gives the average MORB value as $0.15 \pm 0.01$. The samples are plotted in chronological sequence, as in figures 1 and 2. Black diamonds = matrix glasses; green squares = interstitial/embayment glasses; red circles = inclusion glasses. These data, co-located with olivine and glass analyses, are in Appendix A; locations are shown in Appendix B. Open circles are additional $\mathrm{Fe}^{+3} / \mathrm{Fe}^{\mathrm{T}}$ determinations on matrix glasses, given Table 3. One determination on the oxidized rim of sample Iki-26 plots off-scale, as indicated.

Figure 5. Frequency distribution of $\mathrm{K}_{\mathrm{D}}$ values for coexisting olivine-glass pairs in Iki-26 (three areas, see Table 1) and Iki-32 (two areas, see Table 1). Phenocryst rim pairs and the one inclusion pair are shown in gray; microphenocryst and groundmass olivine-melt pairs are shown in green. The values cluster at $\mathrm{K}_{\mathrm{D}}=0.27-0.28$, and the distributions for the two populations largely overlap. See text for further discussion. 
Figure 6. Calculated olivine-melt $\mathrm{K}_{\mathrm{D}}$ values from the histogram in figure 5, plotted against $\mathrm{Fe}^{+3} / \mathrm{Fe}^{\mathrm{T}}$ contents as determined by $\mu$-XANES for samples Iki-26 (3 areas) and Iki-32 (2 areas). Size of symbols matches precision of the data $( \pm 0.005)$. Shaded area covers $K_{D}$ values of $0.280 \pm 0.010$ and encompasses $60 \%$ of the data.

Figure 7. Frequency distribution of $\mathrm{K}_{\mathrm{D}}$ for coexisting olivine-glass pairs in Iki-2 (two areas, see Table 1), Iki-22 (two areas), and Iki-3 (two areas). Pairs from phenocryst rim compositions and an inclusion are shown in gray: microphenocryst and groundmass olivine-melt pairs are shown in red. The distributions overlap except for points on the right, which are associated with the Fe-rich embayed olivine shown in figure 3a.

Figure 8. Frequency distribution of $\mathrm{K}_{\mathrm{D}}$ for coexisting olivine-glass pairs in Iki-44 (three areas, see Table 1) and Iki-5 (two areas). Pairs from phenocryst rims and two inclusions are shown in gray; microphenocryst and groundmass olivine-melt pairs are shown in blue. Both distributions are skewed toward low values, compared with the ranges seen in figs. 5 and 7.

Figure 9. Sulfur contents of glasses from the eight samples of 1959 scoria included in this study. Each point corresponds to an individual microprobe analysis. The samples are plotted in chronological sequence as in figures 1,2 and 4. Glasses in four inclusions and four interstitial areas that were successfully analyzed by $\mu$-XANES are circled in black.

Figure 10. Back-scattered electron images of matrix glasses (gray), plus vesicles (black) and immiscible sulfide blebs (bright) found in glass in two early phase 1 samples of 1959 scoria. (a) Cu-Fe sulfide bleb (10 $\mu \mathrm{m}$ across) in Iki-2, (b) Cu-Ni-Fe bleb (20 $\mu \mathrm{m}$ across) in Iki-22. The blebs appear to be relict: sulfur content of the matrix glasses is $<300 \mathrm{ppm}$, and neither increases nor decreases in the vicinity of the blebs.

Figure 11. Ferric/total iron $\left(\mathrm{Fe}^{+3} / \mathrm{Fe}^{\mathrm{T}}\right)$ ratios of glasses, determined by XANES, plotted against the sulfur content of the glasses. Melts included in olivine are enclosed by the dashed line. Matrix glasses fall below 300 ppm sulfur. Red circles = Iki-2, Iki-22 and Iki-3; the lower (red) line is the least-squares fit for data from Iki-22 and Iki-3 only. Blue triangles = Iki-44, Iki-5 and Iki-10; the upper (blue) line shows the least-squares fit for those from Iki-44 and Iki-5 only. Green inverted triangles = Iki-26, Iki-32. Two processes influence the trends seen: loss of sulfur from the melt before and during eruption, seen in the phase 1 samples, and interaction of the melt with oxygen in the atmosphere during fountaining, seen especially in Iki-26. See text for further discussion.

Figure 12. Sulfur contents of glasses for which XANES determinations are available plotted against their $\mathrm{MgO}$ contents. Data for Iki-2, Iki-22 and Iki-3 are shown by red symbols; data for Iki-44, Iki-5 and Iki-10 shown by blue symbols; data for Iki-26 and Iki-32 shown by green symbols. The dashed line enclosing the $\mathrm{MgO}$ contents of unreconstructed glasses from samples Iki-22 and Iki-3 (Appendix A) leans toward lower MgO contents, suggesting that there has been some overgrowth of adjacent olivine during the air quench. Other red circles are glasses from Iki-2. They and glasses from Iki-5 (see outline) show little lean, suggesting that overgrowths of olivine during the air quench is not resolvable in the less magnesian glasses. 
Figure 13. Photomicrograph of area 2 in Iki-26, showing groundmass olivine crystals in a matrix of vesicular brown glass. Locations of microprobe analyses of olivine (red) and glass (yellow) plus XANES (orange circles and letters) determinations are shown, as is the oxidized rim on the scoria. The XANES traverses are from two different sessions, with data from November 2012 on the left and from March 2013 on the right.

Figure 14. Ferric/total iron $\left(\mathrm{Fe}^{+3} / \mathrm{Fe}^{\mathrm{T}}\right)$ ratios as determined by $\mu$-XANES for various traverses (Fig. 13) in sample Iki-26 plotted against distance from the edge of the glass. Points from three separate traverses in two beam sessions define a single gradient for $\mathrm{Fe}^{+3} / \mathrm{Fe}^{\mathrm{T}}$ in the glass.

Figure 15. Ferric/total iron $\left(\mathrm{Fe}^{+3} / \mathrm{Fe}^{\mathrm{T}}\right)$ ratios of glasses, determined by XANES, plotted against the sulfur content of the glasses. Data and least-squares fit lines for Iki-22 and Iki-3 (red) and for Iki-44 and Iki-5 (blue) as shown in Fig. 11. Gray squares are data from Moussallam et al. (2016), which have been corrected using the modified calibration of Hirschmann et al. (2014). Those shown are melt inclusions in olivine, plus two matrix glasses. Melt inclusions in 1959 scoria are enclosed by the dashed line. Matrix glasses have $\mathrm{S}<300 \mathrm{ppm}$, for all data sets. 
Table 1. Time of eruption and fountain heights for 1959 scoria samples used in the present study, as reported by Murata and Richter (1966) and Richter and others (1970).

\begin{tabular}{ccccc}
\hline Sample number & Date erupted & Time erupted & Phase of eruption & $\begin{array}{c}\text { Fountain height } \\
(\mathrm{m})\end{array}$ \\
\hline Iki-2 & 17 November 1959 & 1500 & 1 & $80-100$ \\
Iki-22 & 18 November 1959 & 1700 & 1 & 320 \\
Iki-3 & 19 November 1959 & 800 & 1 & $320-350$ \\
Iki-44 & 20 November 1959 & 700 & 1 & $240-300$ \\
Iki-5 & 21 November 1959 & 710 & 1 & 240 \\
Iki-10 & 29 November 1959 & 2100 & 3 & 180 \\
Iki-26 & 14 December 1959 & 1400 & 10 & $180-330$ \\
Iki-32 & 17 December 1959 & 1445 & 15 & 580 \\
\hline
\end{tabular}


Table 2. Average matrix glass compositions in areas of 1959 Kilauea scoria samples chosen for XANES analysis.

\begin{tabular}{|c|c|c|c|c|c|c|c|c|c|c|c|c|c|c|c|c|c|}
\hline $\begin{array}{l}\text { Sample } \\
\text { number }\end{array}$ & Iki-2 & Iki-2 & Iki-22 & Iki-22 & Iki-3 & Iki-3 & Iki-44 & Iki-44 & Iki-44 & Iki-5 & Iki-5 & Iki-10 & Iki-26 & Iki-26 & Iki-26 & Iki-32 & Iki-32 \\
\hline $\begin{array}{l}\text { Eruptive } \\
\text { phase }\end{array}$ & 1 & 1 & 1 & 1 & 1 & 1 & 1 & 1 & 1 & 1 & 1 & 3 & 10 & 10 & 10 & 15 & 15 \\
\hline $\begin{array}{l}\text { Area } \\
\text { analyzed }\end{array}$ & $\# 1$ & $\# 2$ & $\# 1$ & $\# 2$ & $\# 1$ & $\# 2$ & $\# 1$ & $\# 2$ & $\# 3$ & $\# 1$ & $\# 2$ & & $\# 1$ & $\# 2$ & $\# 3$ & $\# 1$ & $\# 2$ \\
\hline $\begin{array}{l}\text { Points in } \\
\text { average }\end{array}$ & 5 & 6 & 8 & 8 & 6 & 5 & 3 & 3 & 3 & 9 & 5 & 3 & 7 & 10 & 5 & 4 & 6 \\
\hline $\mathrm{SiO}_{2}$ & 49.91 & 49.93 & 49.30 & 49.41 & 49.37 & 49.41 & 49.70 & 49.66 & 49.76 & 49.71 & 49.65 & 50.13 & 50.15 & 49.90 & 50.12 & 49.76 & 49.70 \\
\hline $\mathrm{TiO}_{2}$ & 2.63 & 2.58 & 2.40 & 2.51 & 2.54 & 2.50 & 2.70 & 2.56 & 2.70 & 2.75 & 2.63 & 2.81 & 2.76 & 2.65 & 2.63 & 2.69 & 2.67 \\
\hline $\mathrm{Al}_{2} \mathrm{O}_{3}$ & 12.85 & 12.87 & 12.30 & 12.35 & 12.28 & 12.36 & 13.07 & 12.95 & 12.97 & 13.18 & 13.29 & 13.54 & 13.34 & 13.04 & 13.06 & 13.01 & 12.91 \\
\hline $\mathrm{Cr}_{2} \mathrm{O}_{3}$ & 0.08 & 0.06 & 0.09 & 0.08 & 0.09 & 0.08 & 0.06 & 0.06 & 0.06 & 0.04 & 0.06 & 0.03 & 0.05 & 0.06 & 0.05 & 0.08 & 0.07 \\
\hline $\mathrm{FeO}$ & 11.32 & 11.14 & 11.31 & 11.28 & 11.27 & 11.39 & 11.30 & 11.37 & 11.37 & 11.39 & 11.10 & 11.05 & 10.72 & 11.27 & 11.19 & 10.88 & 11.16 \\
\hline $\mathrm{MnO}$ & 0.19 & 0.17 & 0.19 & 0.17 & 0.18 & 0.17 & 0.18 & 0.17 & 0.18 & 0.17 & 0.17 & 0.19 & 0.16 & 0.16 & 0.15 & 0.18 & 0.18 \\
\hline $\mathrm{MgO}$ & 8.61 & 8.51 & 10.15 & 10.14 & 10.08 & 10.05 & 8.64 & 8.59 & 8.69 & 7.71 & 7.73 & 7.48 & 8.20 & 8.61 & 8.71 & 8.78 & 8.89 \\
\hline $\mathrm{CaO}$ & 11.79 & 11.59 & 11.35 & 11.30 & 11.29 & 11.29 & 11.30 & 11.31 & 11.37 & 11.52 & 11.39 & 11.60 & 11.63 & 11.55 & 11.50 & 11.46 & 11.39 \\
\hline $\mathrm{Na}_{2} \mathrm{O}$ & 2.07 & 2.11 & 1.97 & 1.97 & 1.98 & 1.99 & 2.04 & 2.17 & 2.08 & 2.18 & 2.16 & 2.16 & 2.07 & 2.08 & 2.08 & 2.10 & 2.10 \\
\hline $\mathrm{K}_{2} \mathrm{O}$ & 0.54 & 0.51 & 0.49 & 0.49 & 0.50 & 0.50 & 0.50 & 0.49 & 0.50 & 0.57 & 0.55 & 0.58 & 0.54 & 0.52 & 0.53 & 0.55 & 0.54 \\
\hline
\end{tabular}




\begin{tabular}{|c|c|c|c|c|c|c|c|c|c|c|c|c|c|c|c|c|c|}
\hline $\mathrm{P}_{2} \mathrm{O}_{5}$ & 0.24 & 0.25 & 0.22 & 0.23 & 0.23 & 0.24 & 0.24 & 0.24 & 0.23 & 0.25 & 0.26 & 0.25 & 0.24 & 0.25 & 0.24 & 0.23 & 0.25 \\
\hline \multirow[t]{2}{*}{ Sum } & 100.23 & 99.72 & 99.77 & 99.93 & & 99.98 & 99.71 & 99.56 & & 99.47 & 98.99 & 99.82 & & 100.09 & 100.37 & 99.73 & 99.98 \\
\hline & & & & & 99.80 & & & & 99.91 & & & & 99.86 & & & & \\
\hline $\begin{array}{l}\text { Sulfur } \\
(\mathrm{ppm})\end{array}$ & 135 & 122 & 118 & 151 & 130 & 86 & 132 & 83 & 159 & 104 & 94 & 84 & 34 & 73 & 30 & 23 & 75 \\
\hline $\begin{array}{l}\mathrm{T} \\
(\mathrm{MgO}),{ }^{\circ} \mathrm{C}^{\mathrm{a}}\end{array}$ & 1188 & 1185 & 1217 & 1220 & 1218 & 1217 & 1191 & 1188 & 1187 & 1169 & 1169 & 1164 & 1177 & 1188 & 1195 & 1191 & 1194 \\
\hline $\begin{array}{l}\mathrm{S}-1 /(\mathrm{S}- \\
1+\mathrm{S}-2) \mathrm{b}\end{array}$ & 0.63 & 0.63 & 0.68 & 0.68 & $\sim 0.70$ & $\sim 0.70$ & 0.06 & 0.06 & 0.06 & 0.12 & 0.12 & 0.0 & 0.21 & 0.21 & 0.21 & 0.40 & 0.40 \\
\hline NMNH ID & 1161 & & 1161 & $11-22$ & 1161 & $11-3$ & & $116111-44$ & & 116 & $11-5$ & $\begin{array}{c}116111- \\
10\end{array}$ & & $116111-26$ & & 1161 & $11-32$ \\
\hline
\end{tabular}

${ }^{a}$ Glass quenching temperatures estimated from Helz and Thornber (1987).

${ }^{b}$ Mixing ratios of S-1 and S-2 are for sample bulk compositions, as given in Wright (1973). 
Table 3. Initial XANES determinations of $\mathrm{Fe}^{+3} / \mathrm{Fe}^{T}$ ratios for matrix glasses in four 1959 scoria samples

\begin{tabular}{cccc}
\hline Sample & Date of analysis & $\mathrm{Fe}^{+3} / \mathrm{Fe}^{\mathrm{T}}$ values & Range of $\mathrm{Fe}^{+3} / \mathrm{Fe}^{\mathrm{T}}$ \\
\hline Iki-22 & August 2011 & $0.121 \pm 0.007 \quad(3 \mathrm{pts})$ & 0.014 \\
Iki-3 & August 2011 & $0.116,0.112,0.120$ & 0.008 \\
Iki-26 & March 2012 & $0.210,0.178,0.310$ & 0.132 \\
Iki-32 & March 2012 & $0.138,0.138,0.135$ & 0.003 \\
\hline
\end{tabular}


Table 4. Composition of melt inclusions in 1959 scoria for which $\mu$-XANES data were obtained. The inclusion in Iki-3 has been adjusted for olivine overgrowth so that its corrected $\mathrm{MgO}$ content matches that of the host glass.

\begin{tabular}{|c|c|c|c|c|c|}
\hline Sample & Iki-3 & $\begin{array}{l}\text { Iki-3 plus } \\
1.55 \% \text { olivine }\end{array}$ & Iki-44 & Iki-5 & Iki-32 \\
\hline $\begin{array}{l}\text { NMNH } \\
\text { sample ID }\end{array}$ & $116111-3$ & $116111-3$ & $116111-44$ & $116111-5$ & $116111-32$ \\
\hline No. points & 2 & 2 & 2 & 2 & 2 \\
\hline $\mathrm{SiO}_{2}$ & 48.38 & 48.25 & 49.37 & 49.19 & 49.48 \\
\hline $\mathrm{TiO}_{2}$ & 2.60 & 2.56 & 2.32 & 2.46 & 2.70 \\
\hline $\mathrm{Al}_{2} \mathrm{O}_{3}$ & 12.04 & 11.84 & 12.03 & 12.54 & 13.05 \\
\hline $\mathrm{Cr}_{2} \mathrm{O}_{3}$ & 0.10 & 0.10 & 0.12 & 0.06 & 0.06 \\
\hline $\mathrm{FeO}$ & 12.04 & 12.08 & 11.64 & 11.46 & 10.00 \\
\hline $\mathrm{MnO}$ & 0.20 & 0.20 & 0.18 & 0.18 & 0.15 \\
\hline $\mathrm{MgO}$ & 9.48 & 10.06 & 8.73 & 7.70 & 8.86 \\
\hline $\mathrm{CaO}$ & 11.23 & 11.06 & 12.44 & 12.43 & 12.05 \\
\hline $\mathrm{Na}_{2} \mathrm{O}$ & 1.82 & 1.82 & 1.67 & 1.82 & 2.08 \\
\hline $\mathrm{K}_{2} \mathrm{O}$ & 0.47 & 0.47 & 0.40 & 0.48 & 0.54 \\
\hline $\mathrm{P}_{2} \mathrm{O}_{5}$ & 0.25 & 0.25 & 0.22 & 0.24 & 0.27 \\
\hline Sum & 98.61 & 98.69 & 99.12 & 98.56 & 99.24 \\
\hline $\begin{array}{l}\text { Sulfur } \\
(\mathrm{ppm})\end{array}$ & 1344 & 1324 & 1322 & 1255 & 1164 \\
\hline $\mathrm{Fe}^{+3} / \mathrm{Fe}^{\mathrm{T}}$ & 0.175 & 0.174 & $0.168,0.172$ & $0.170,0.174$ & $0.157,0.161$ \\
\hline
\end{tabular}




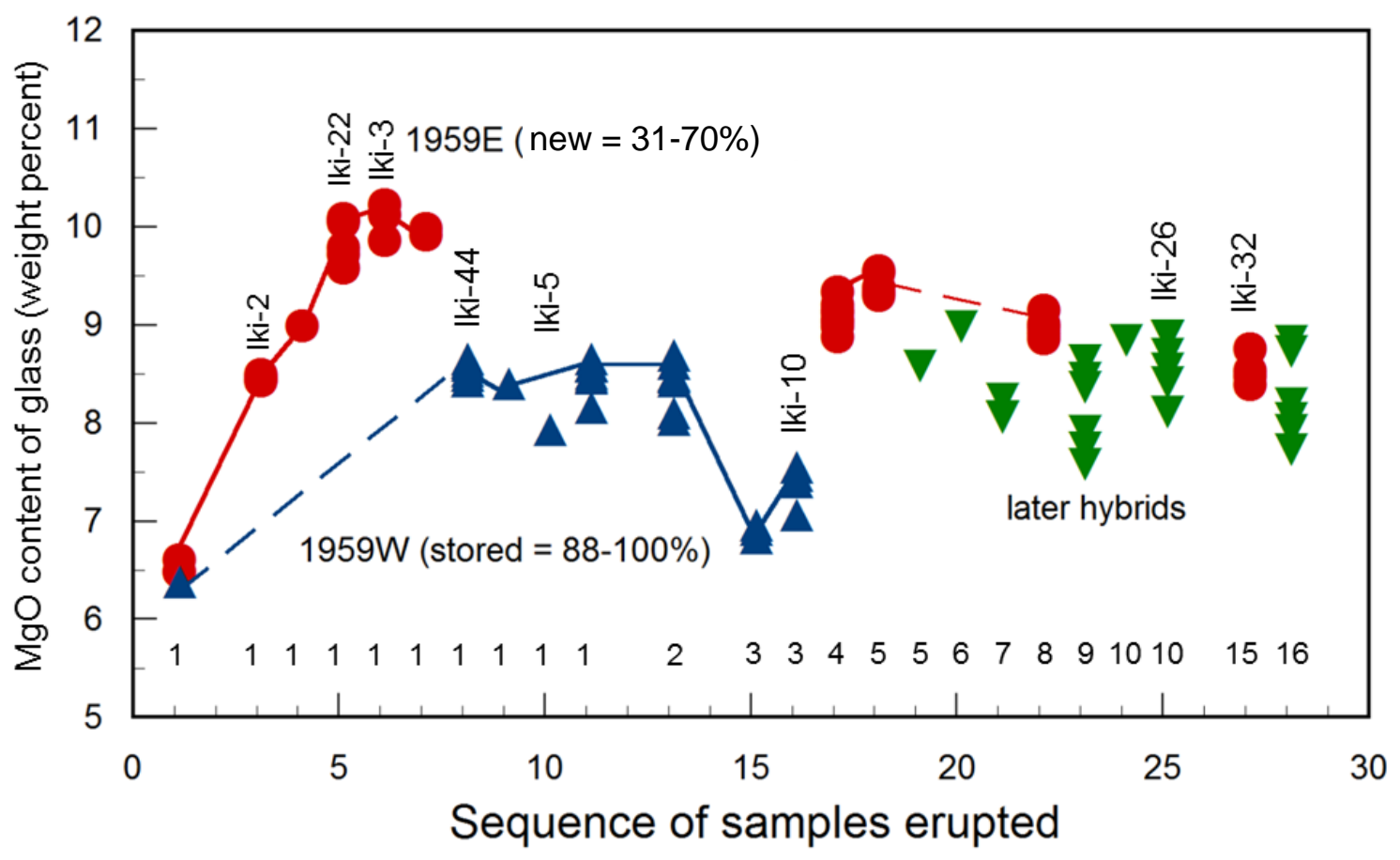




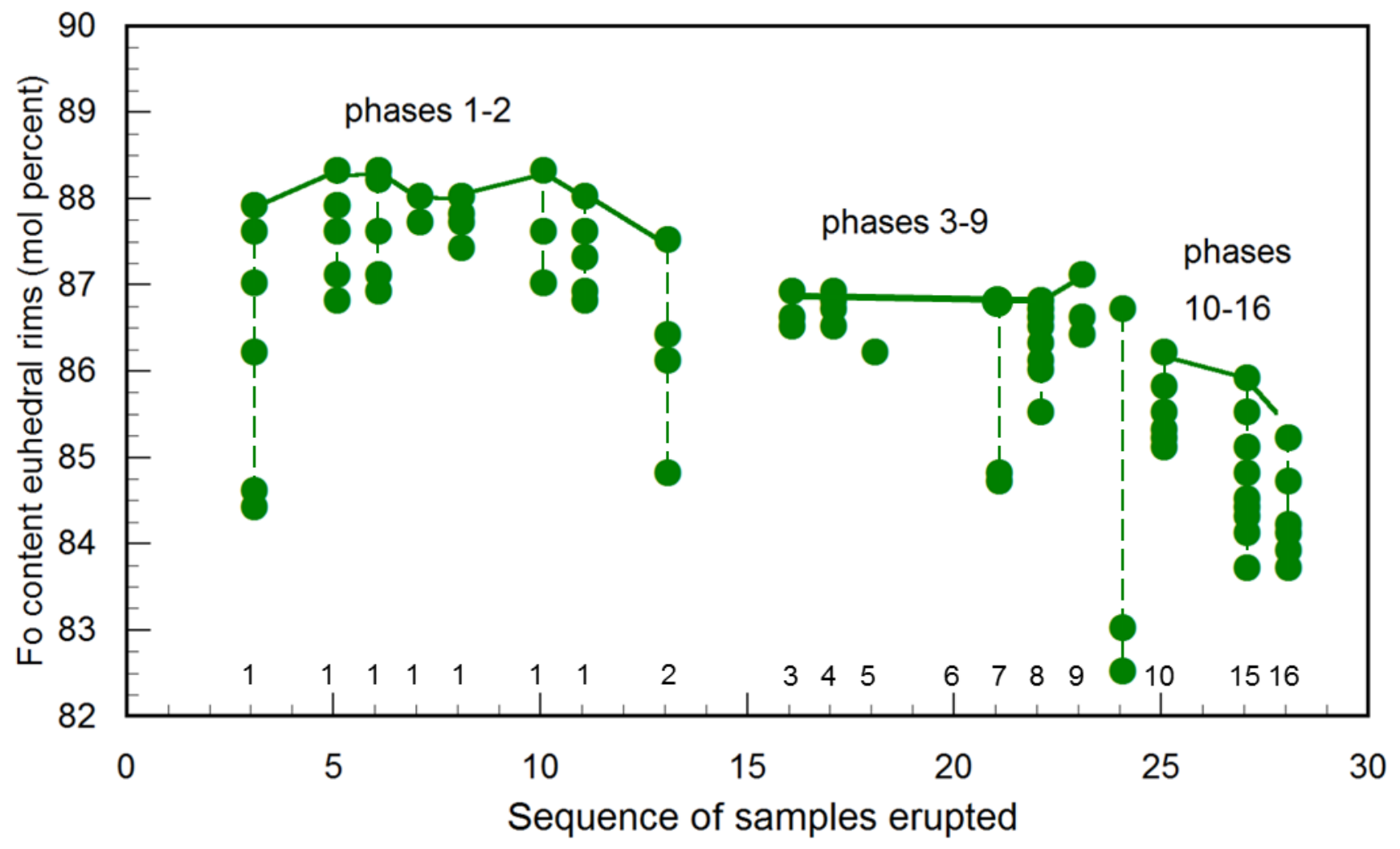




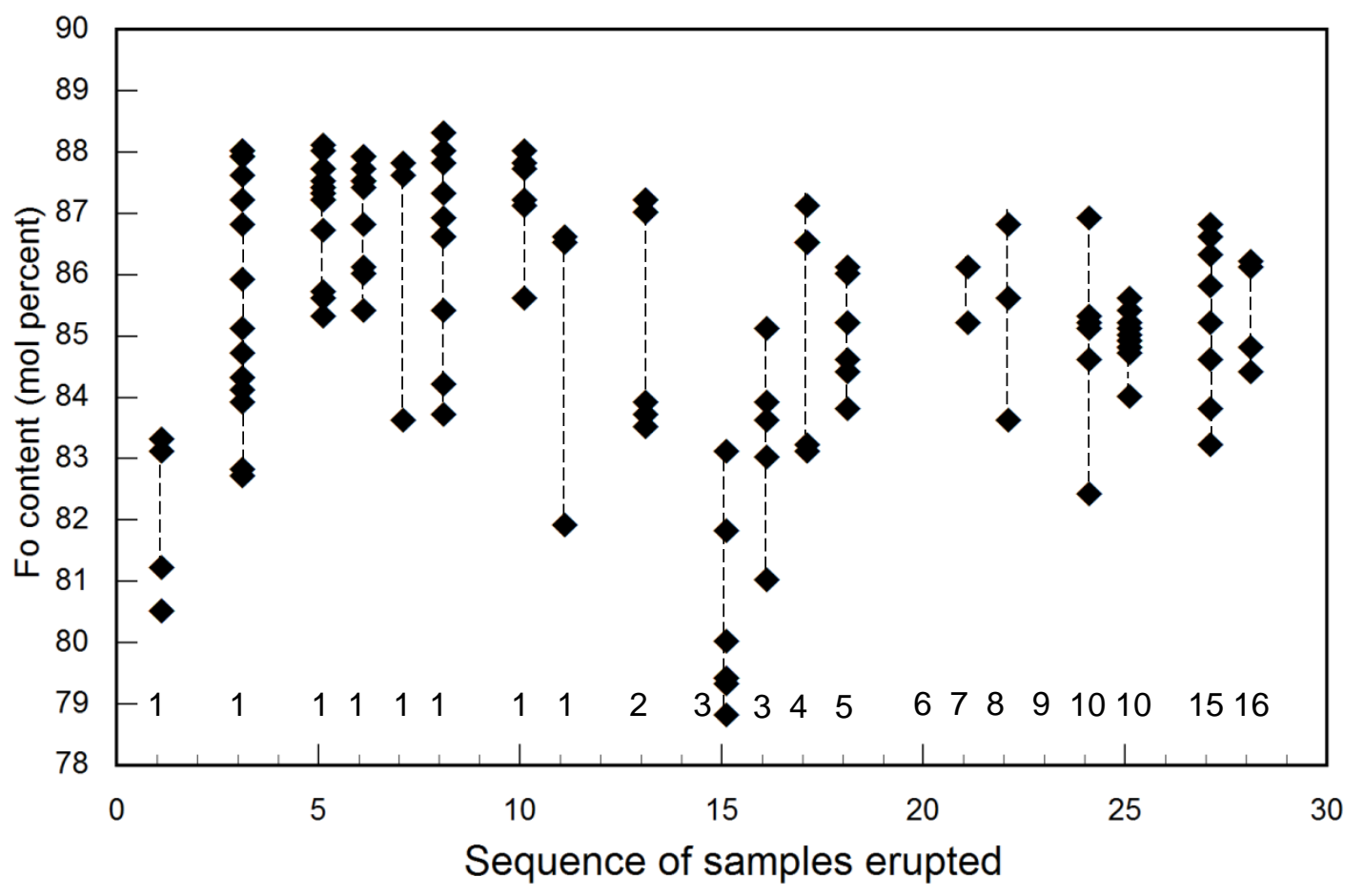




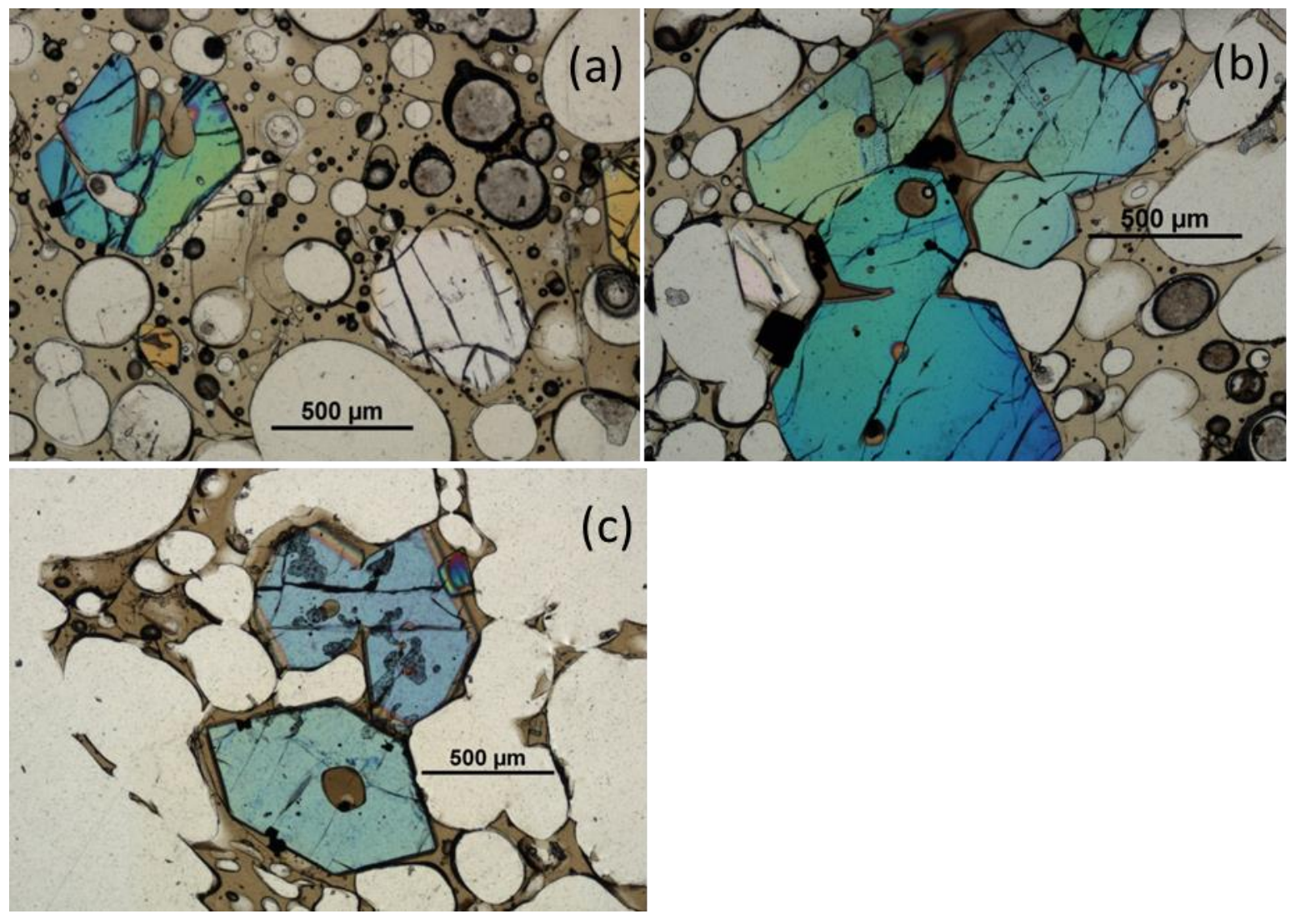




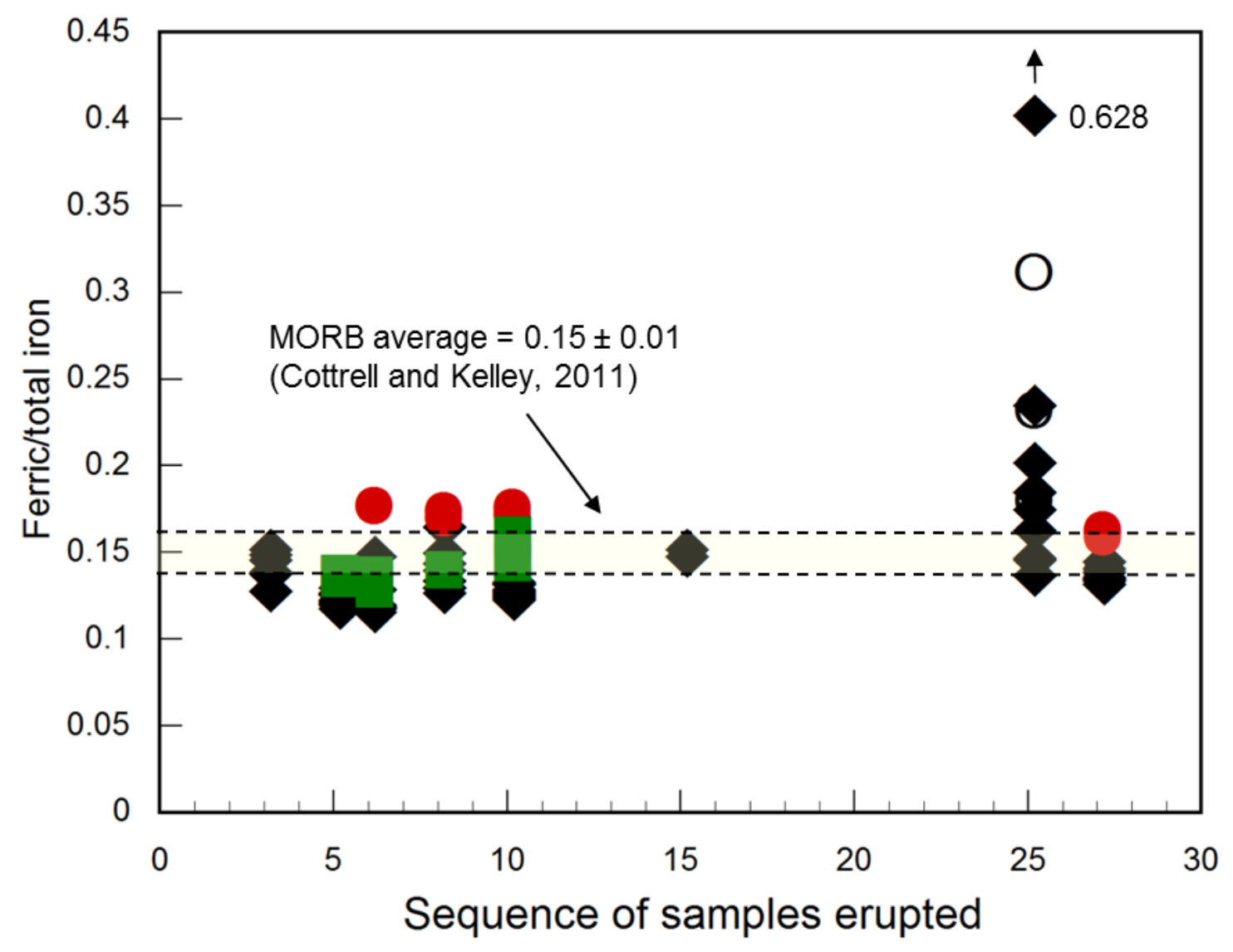




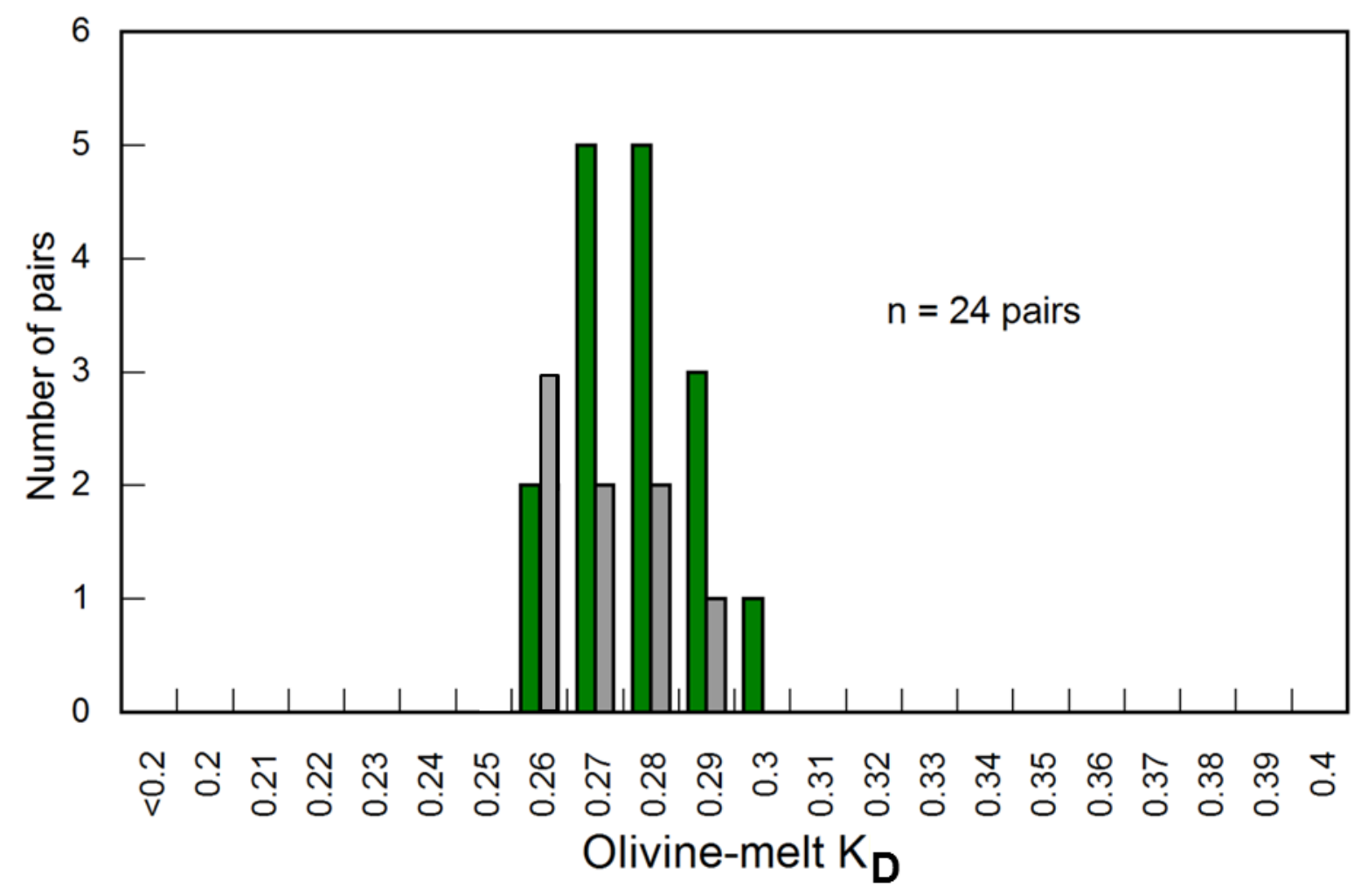




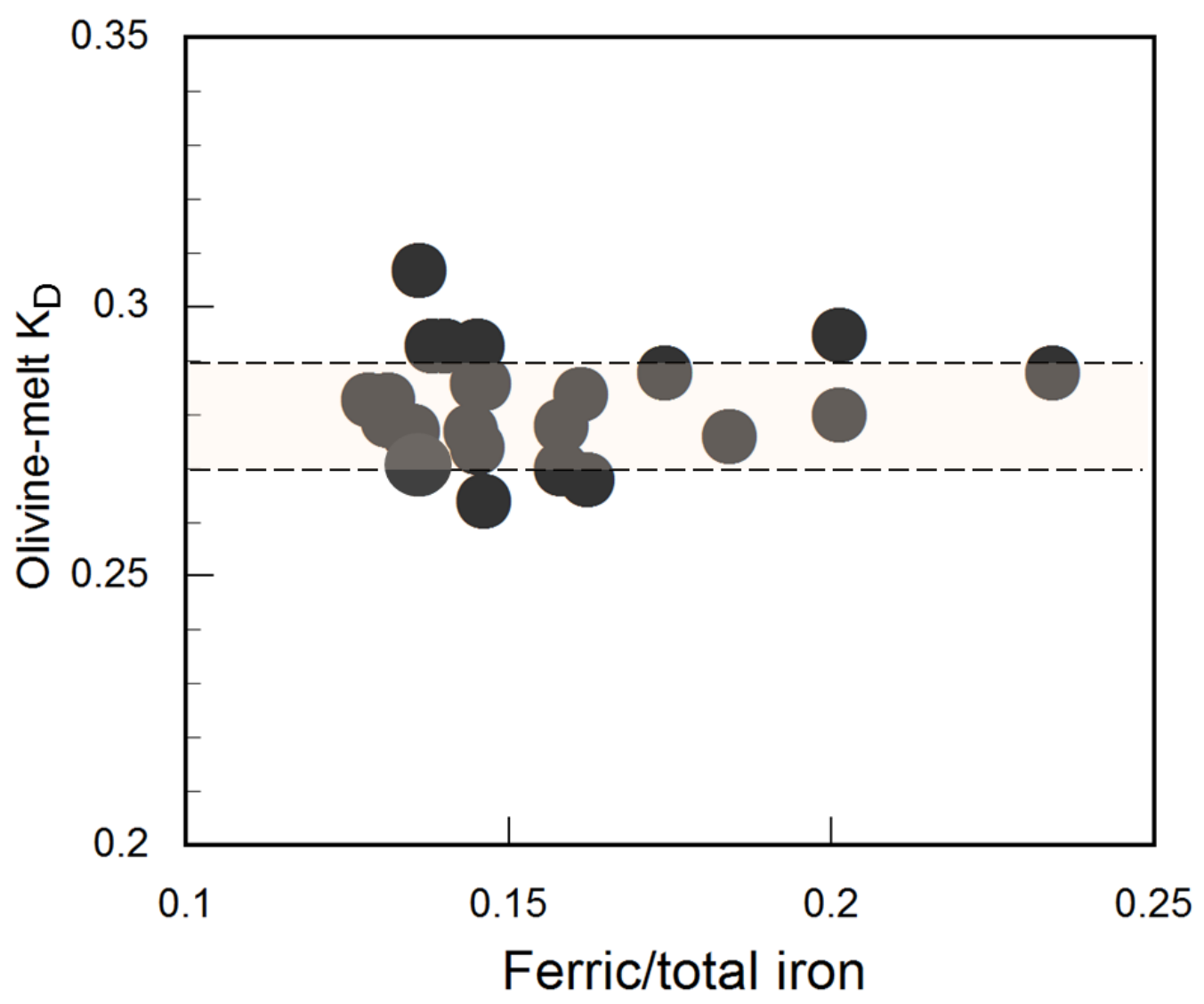




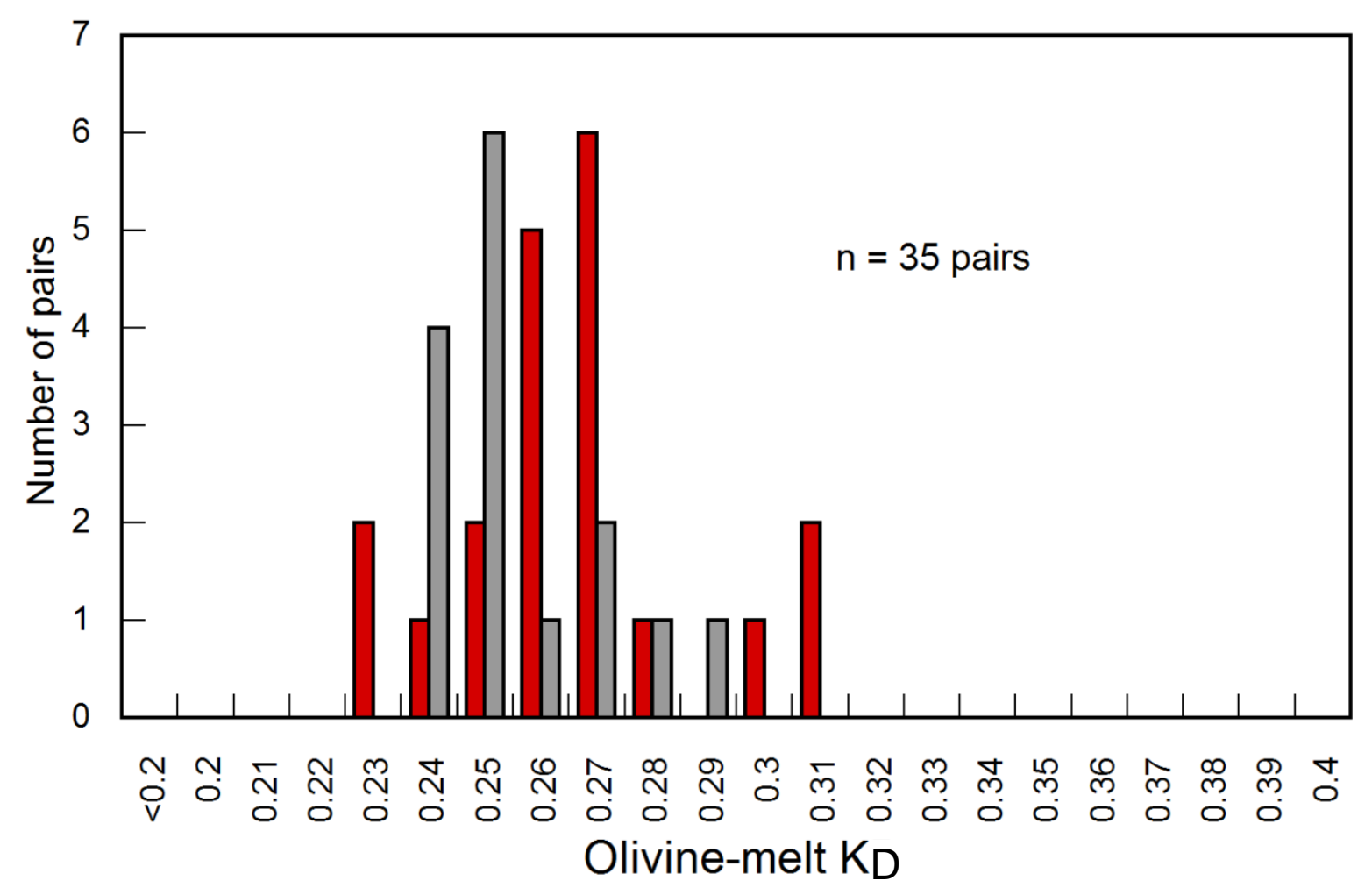




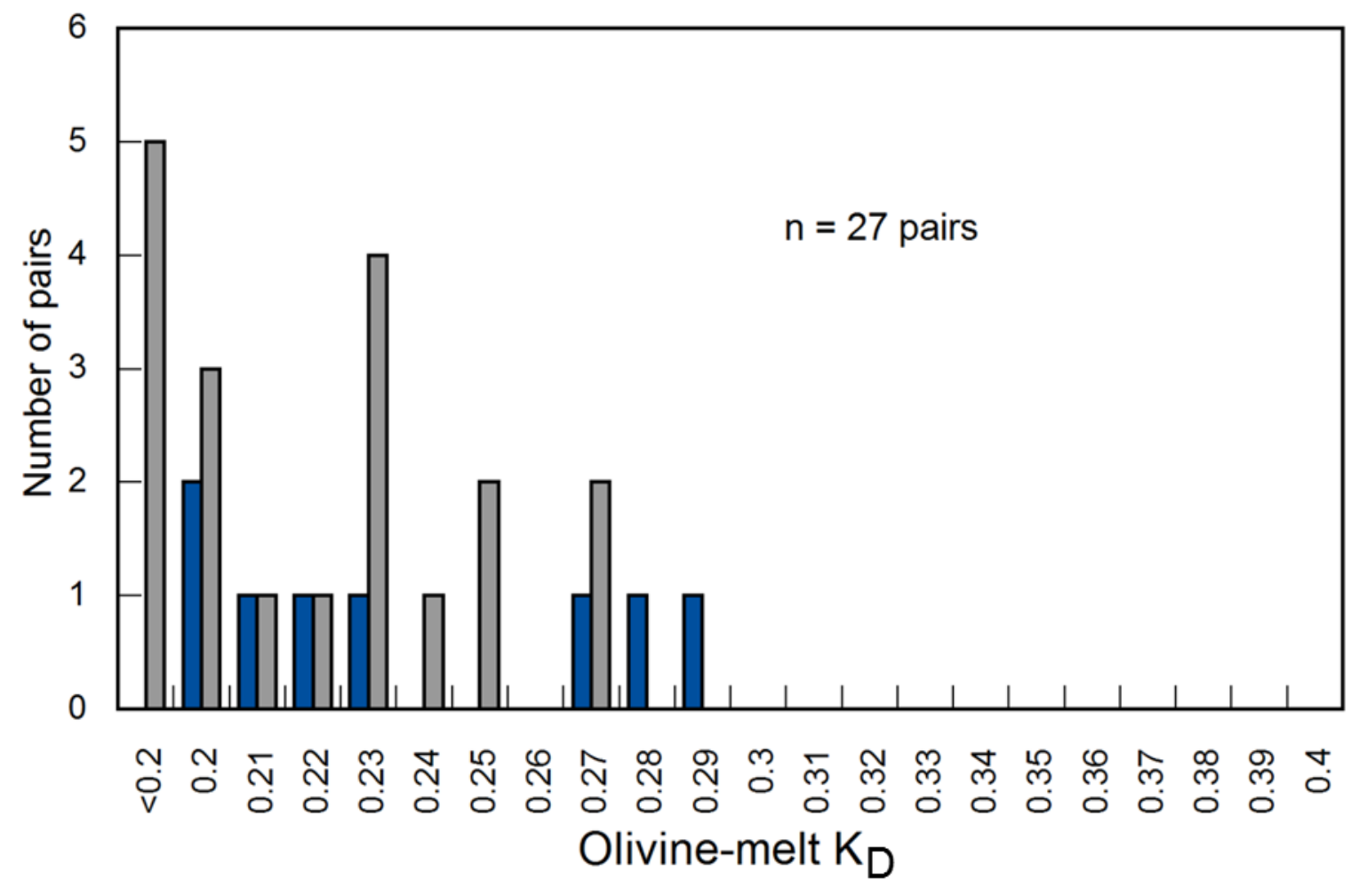




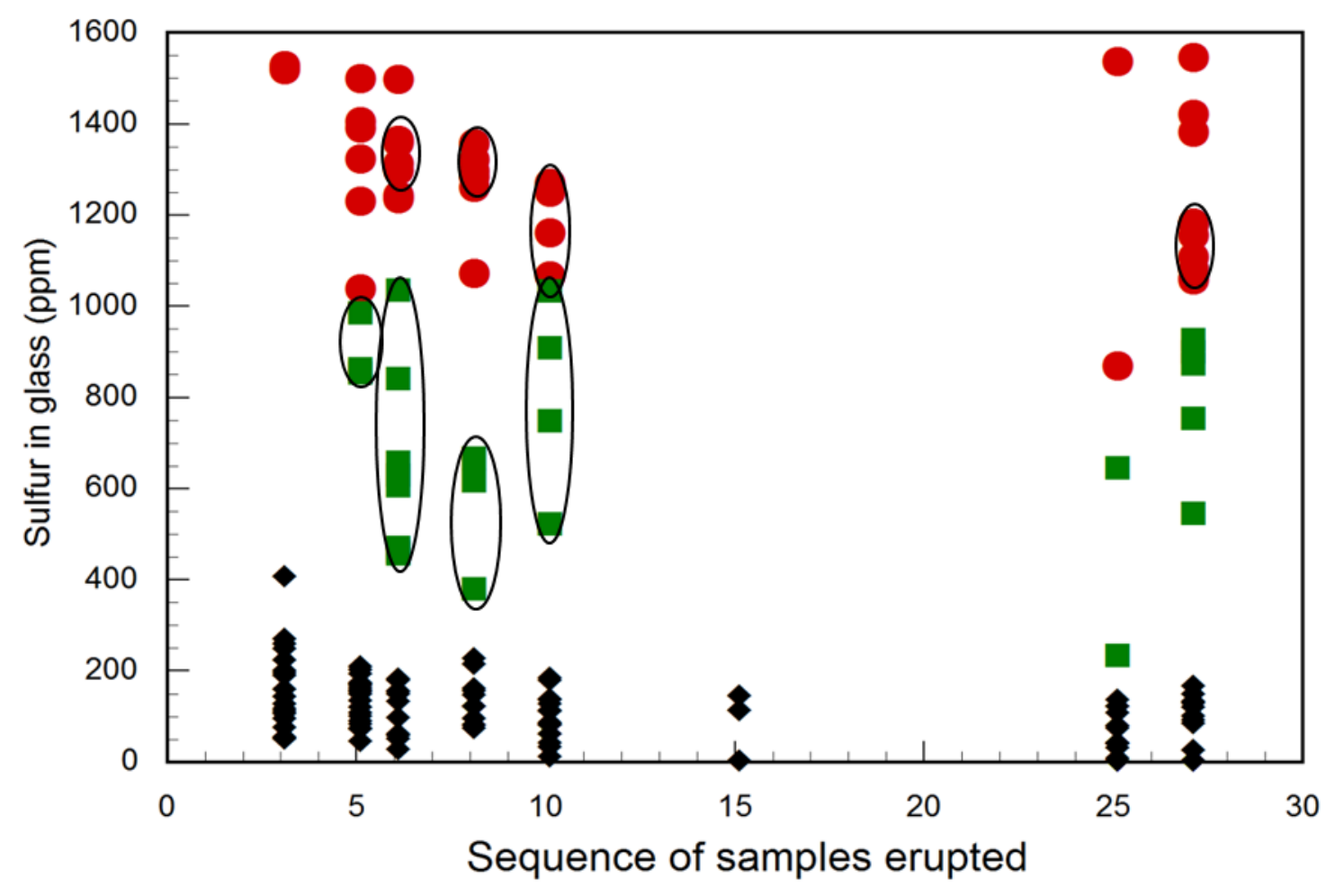




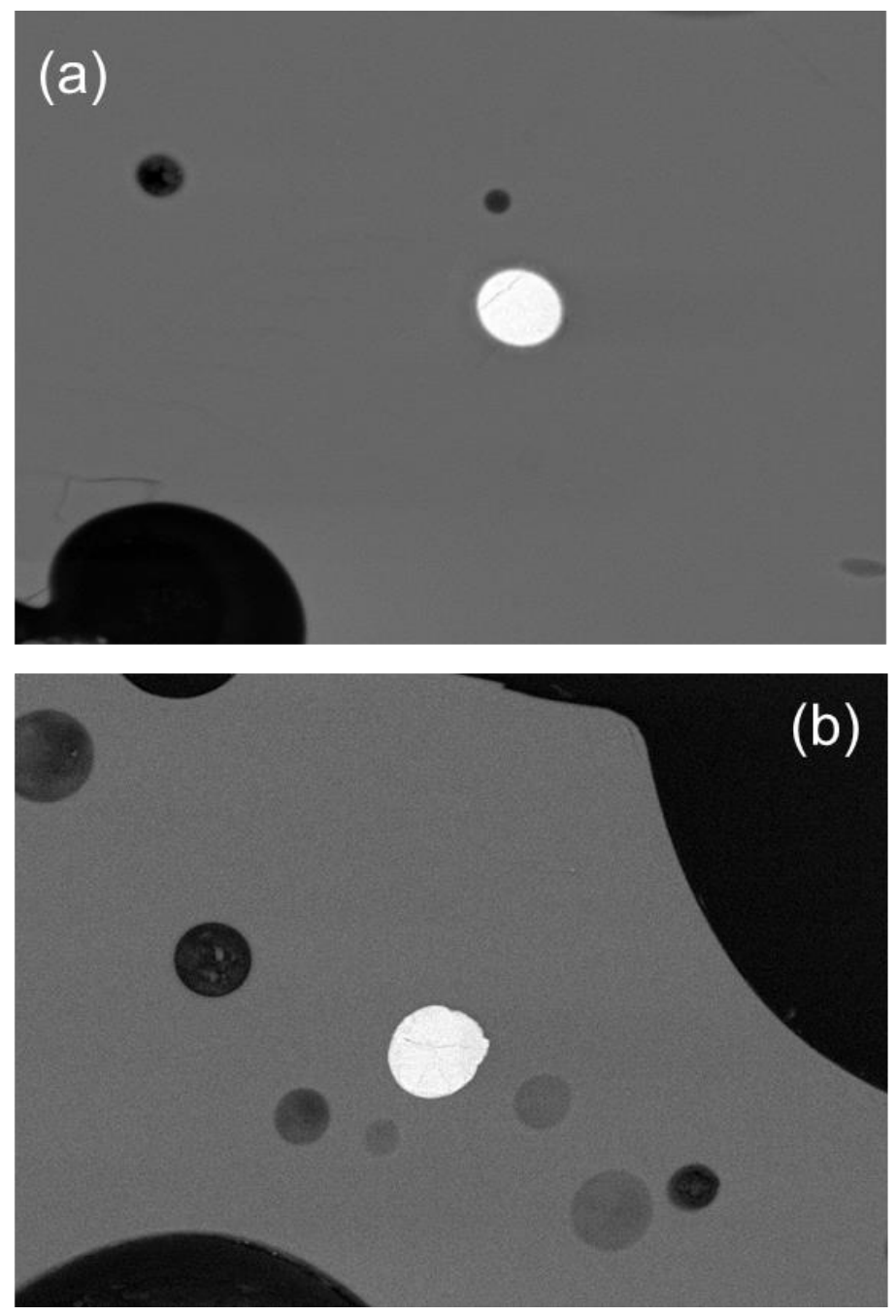




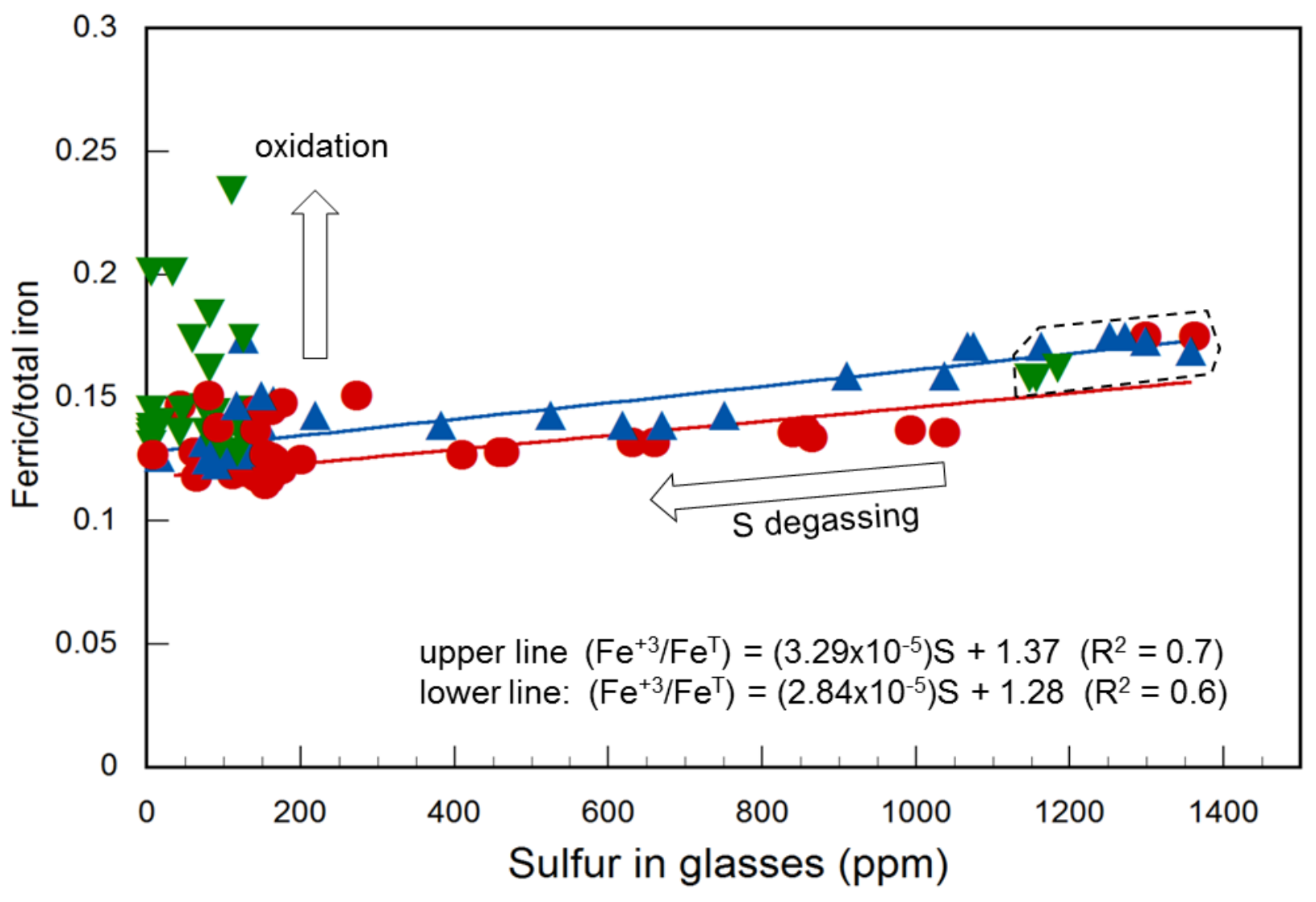




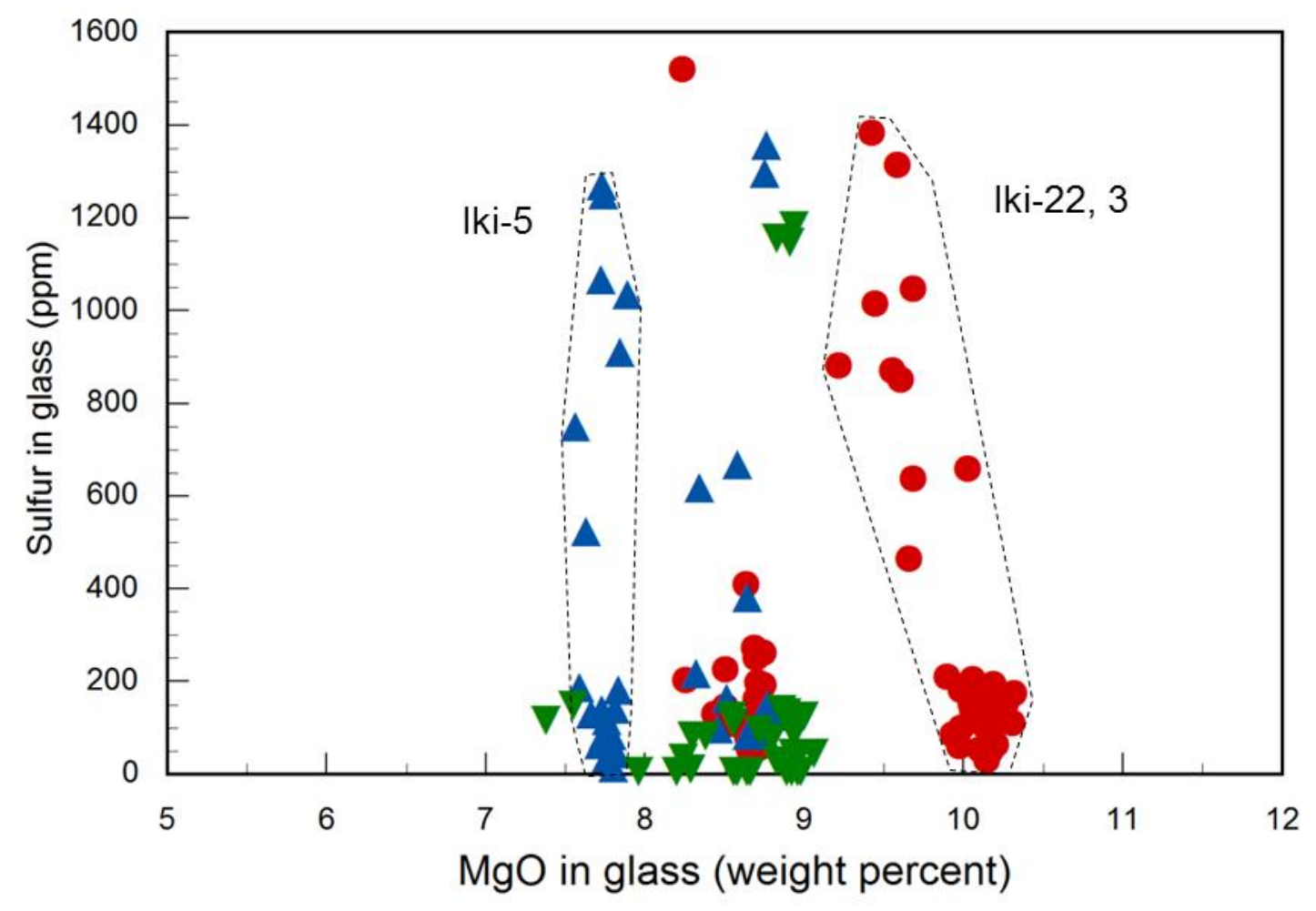




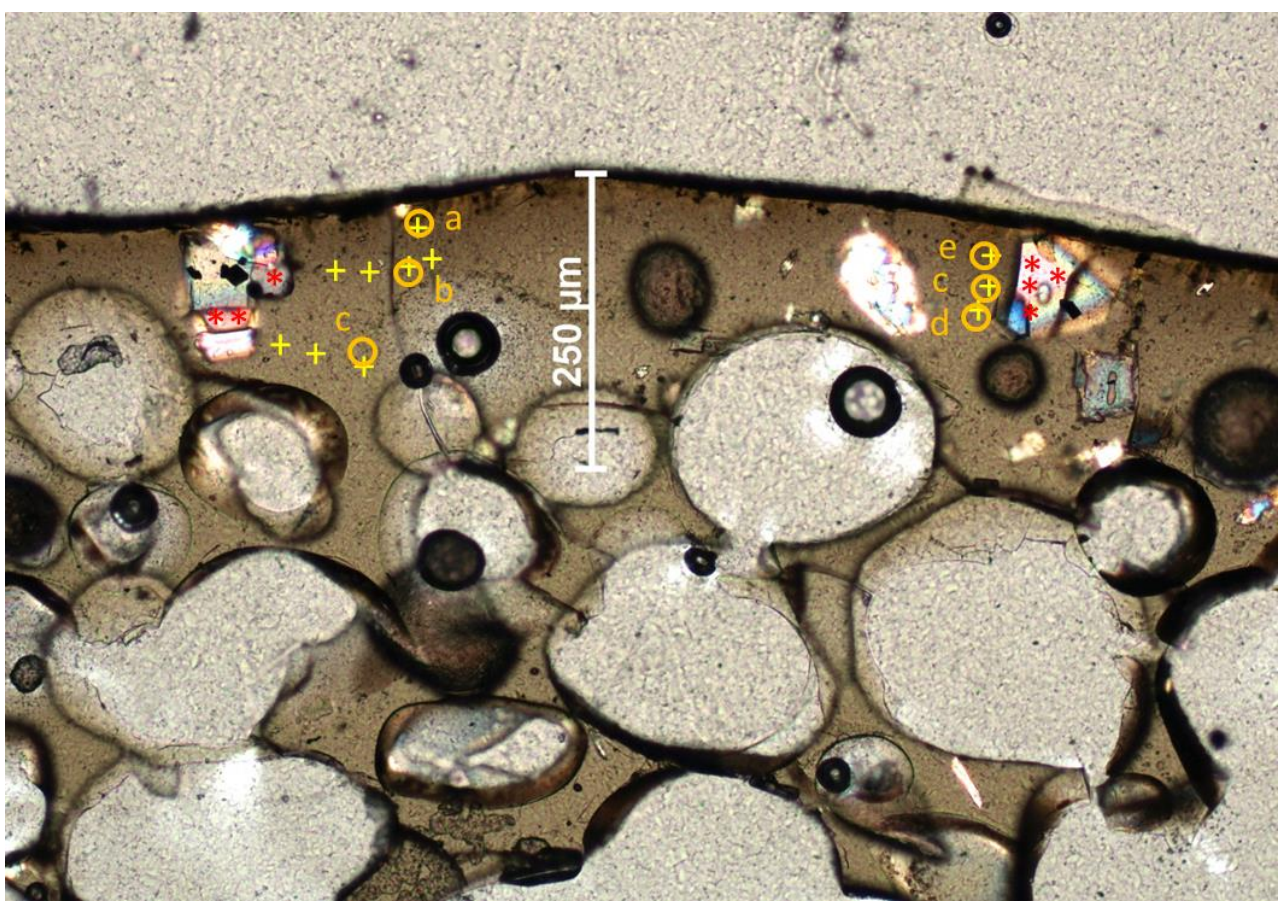




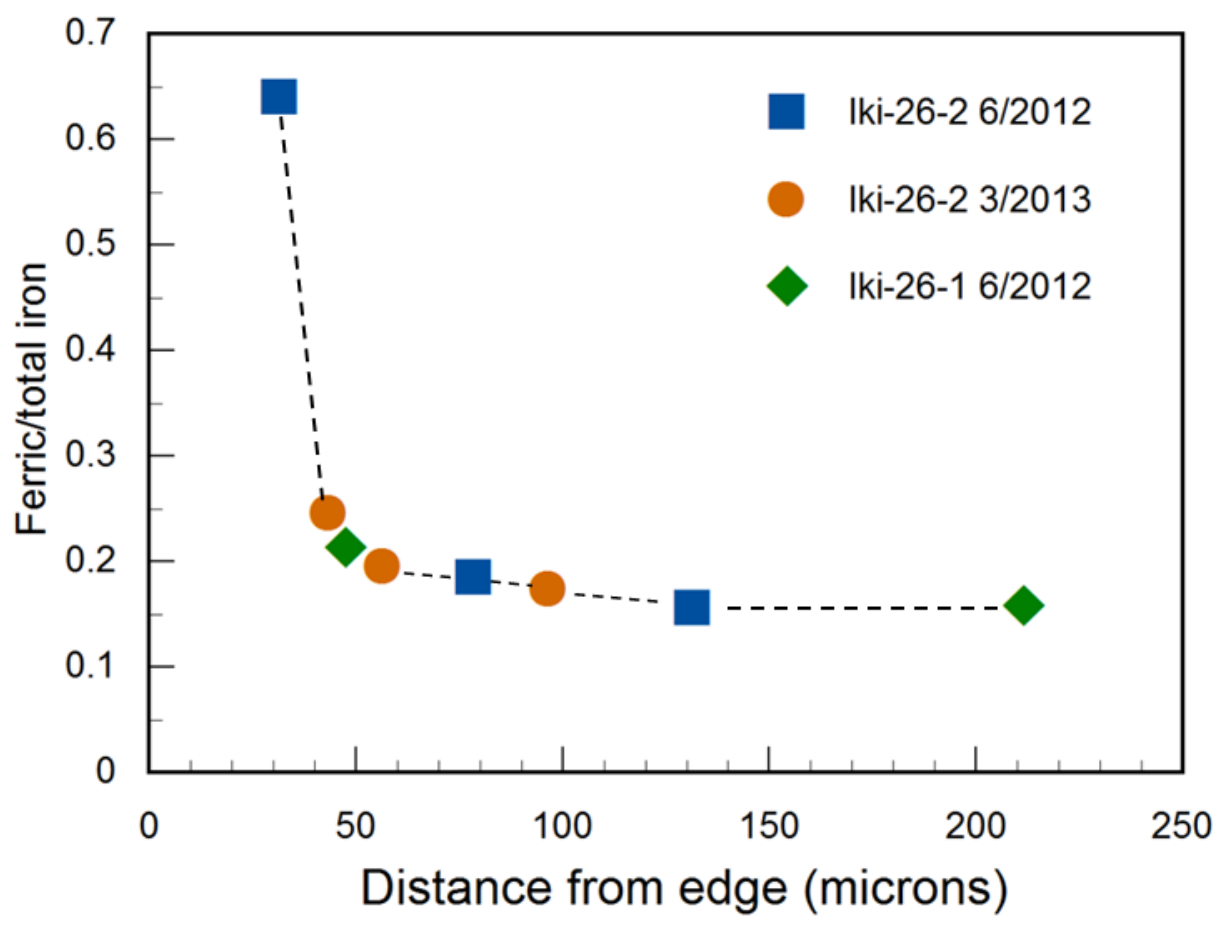




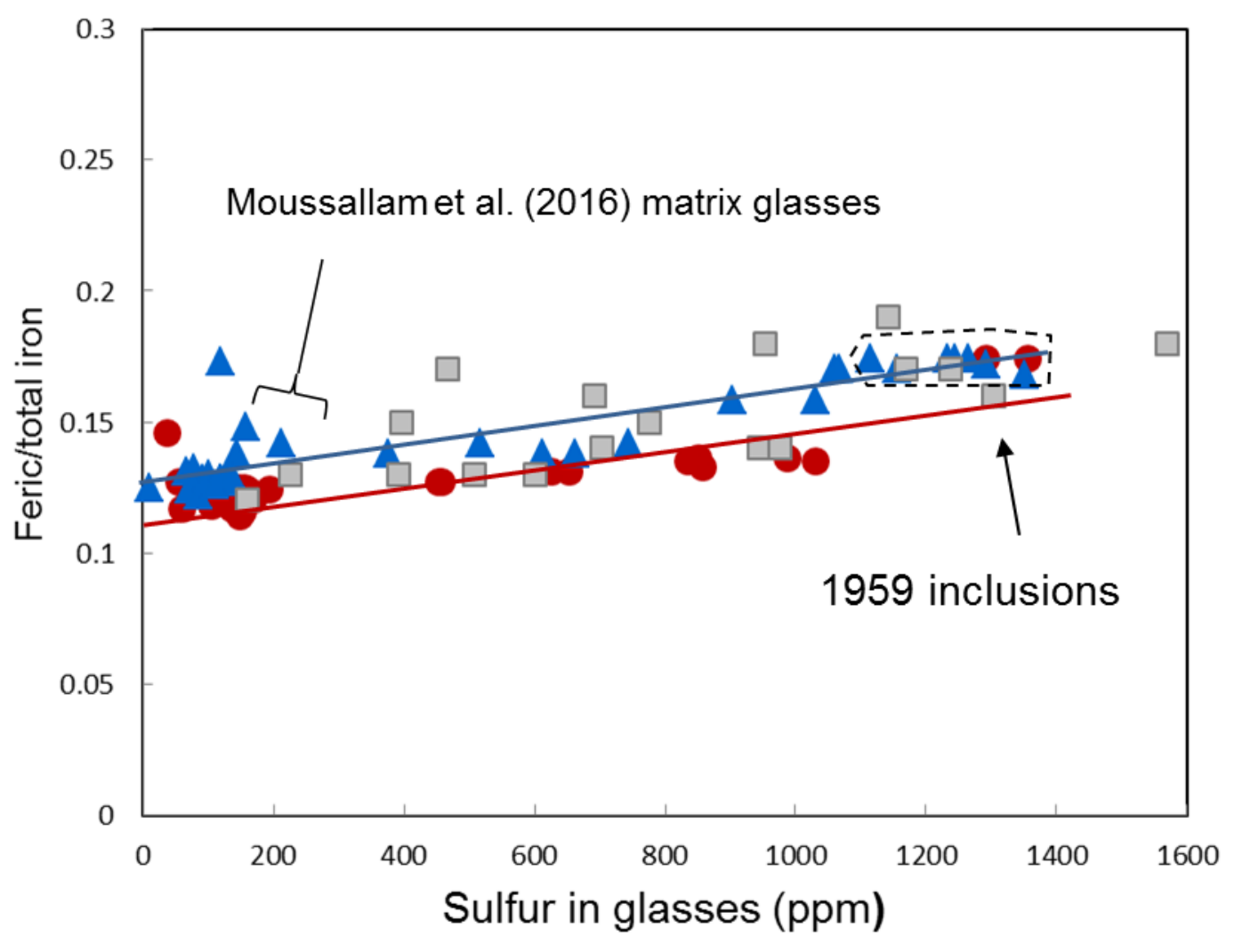

